\title{
PII S0016-7037(99)00217-3
}

\section{Effects of growth rate, $\mathrm{CO}_{2}$ concentration, and cell size on the stable carbon isotope fractionation in marine phytoplankton}

\author{
StefFen Burkhardt,* Ulf Riebesell, and Ingrid Zondervan \\ Alfred Wegener Institute for Polar and Marine Research, Am Handelshafen 12, D-27570 Bremerhaven, Germany
}

(Received December 14, 1998; accepted in revised form June 7, 1999)

\begin{abstract}
Stable carbon isotope fractionation $\left(\varepsilon_{\mathrm{p}}\right)$ was measured in four marine diatom and one dinoflagellate species of different cell sizes. Monospecific cultures were incubated under high-light and nutrient-replete

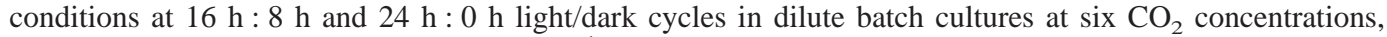
$\left[\mathrm{CO}_{2, \mathrm{aq}}\right]$, ranging from ca. 1 to $38 \mu \mathrm{mol} \mathrm{kg}{ }^{-1}$. In all species, $\varepsilon_{\mathrm{p}}$ increased with increasing $\left[\mathrm{CO}_{2, \mathrm{aq}}\right]$. Among the diatoms, the degree of $\mathrm{CO}_{2}$-related variability in $\varepsilon_{\mathrm{p}}$ was inversely correlated with cell size. Isotopic fractionation in the dinoflagellate differed in several aspects from that of the diatoms, which may reflect both morphological and physiological differences between taxa. Daylength-related changes in instantaneous growth rate, defined as the rate of $\mathrm{C}$ assimilation during the photoperiod, affected $\varepsilon_{\mathrm{p}}$ to a similar or greater extent than differences in experimental $\left[\mathrm{CO}_{2, \mathrm{aq}}\right]$ in three of the species tested. In contrast, the irradiance cycle had no effect on $\varepsilon_{\mathrm{p}}$ in 2 other species. With the exception of Phaeodactylum tricornutum, growth rate of all species declined below a critical $\left[\mathrm{CO}_{2, \text { aq }}\right]$. At these concentrations, we observed a reversal in the $\mathrm{CO}_{2}$-related $\varepsilon_{\mathrm{p}}$ trend, which we attribute to a decline in carbon assimilation efficiency. Although uncatalyzed passive diffusion of $\mathrm{CO}_{2}$ into the cell was sufficient to account for gross carbon uptake in most treatments, our results indicate that other processes contribute to inorganic carbon acquisition in all species even at $\left[\mathrm{CO}_{2, \mathrm{aq}}\right]>10$ $\mu \mathrm{mol} \mathrm{kg}{ }^{-1}$. These processes may include active $\mathrm{C}$ transport and/or catalyzed conversion of $\mathrm{HCO}_{3}^{-}$to $\mathrm{CO}_{2}$ by carbonic anhydrase. A comparison of our results with data from the literature indicates significant deviations from previously reported correlations between $\varepsilon_{\mathrm{p}}$ and $\mu /\left[\mathrm{CO}_{2, \text { aq }}\right]$, even when differences in cellular carbon content and cell geometry are accounted for. Copyright (c) 1999 Elsevier Science Ltd
\end{abstract}

\section{INTRODUCTION}

During photosynthetic fixation of $\mathrm{CO}_{2}$ into organic material, algal cells discriminate against the heavier stable carbon isotope ${ }^{13} \mathrm{C}$. As a result of this fractionation process, marine phytoplankton are depleted in ${ }^{13} \mathrm{C}$ relative to the inorganic carbon source. Variations in the isotopic composition $\left(\delta^{13} \mathrm{C}\right)$ of sedimentary organic carbon have been correlated with concentrations of molecular dissolved $\mathrm{CO}_{2},\left[\mathrm{CO}_{2, \mathrm{aq}}\right]$, in surface water (Rau et al., 1989, 1992) with marine plankton being most depleted in ${ }^{13} \mathrm{C}$ at high latitudes (Sackett et al., 1965; Rau et al., 1982, 1989). This led to the suggestion that isotope measurements of sedimentary organic matter may be used for the reconstruction of ancient $\mathrm{CO}_{2}$ concentrations in ocean surface waters (e.g., Freeman and Hayes, 1992; Jasper et al., 1994; Rau, 1994).

Factors other than $\mathrm{CO}_{2}$, however, may also have a significant impact on the isotopic composition in microalgae. Algal growth rate $(\mu)$ is a key variable in the fractionation process and isotopic fractionation in mixed phytoplankton assemblages can be influenced by taxon-specific differences (e.g., Francois et al., 1993; Goericke et al., 1994; Laws et al., 1995; Rau et al., 1996; Popp et al., 1998). Furthermore, the nutritional status of the cells may affect isotope fractionation (Kukert and Riebesell, 1998).

An inverse correlation is predicted for $\varepsilon_{\mathrm{p}}$ as a function of $\mu /\left[\mathrm{CO}_{2, \mathrm{aq}}\right]$ (Francois et al., 1993; Laws et al., 1995, 1997; Rau et al., 1996). At $\mathrm{CO}_{2}$ concentrations exceeding $10 \mu \mathrm{mol} \mathrm{kg}{ }^{-1}$,

* Author to whom correspondence should be addressed (sburkhardt@awi-bremerhaven.de). linearity of this relationship has been demonstrated for the diatoms Phaeodactylum tricornutum (Laws et al., 1995), Porosira glacialis (Popp et al., 1998), and for the coccolithophorid Emiliania huxleyi (Bidigare et al., 1997). Differences in the slopes of $\varepsilon_{\mathrm{p}}$ vs. $\mu /\left[\mathrm{CO}_{2, \mathrm{aq}}\right]$ regression lines between these species could be accounted for by differences in the surface area and cellular carbon content (Popp et al., 1998). These results are consistent with (but do not prove) $\mathrm{CO}_{2}$ being the carbon species entering the cell. It is important to keep in mind that one cannot distinguish between $\mathrm{CO}_{2}$ and $\mathrm{HCO}_{3}^{-}$uptake in algal cells based on isotope data alone, if they are not accompanied by additional information (Laws et al., 1997; Keller and Morel, 1999).

Regardless of the carbon acquisition mechanism, Popp et al. (1998) conclude that the empirical relationship between $\varepsilon_{\mathrm{p}}$ and $\mu /\left[\mathrm{CO}_{2, \mathrm{aq}}\right]$ may be used to determine paleo- $\left[\mathrm{CO}_{2, \mathrm{aq}}\right]$, when growth rates, cell size, and geometry can be constrained. Alternatively, in situ growth rates of phytoplankton could be estimated from $\varepsilon_{\mathrm{p}},\left[\mathrm{CO}_{2, \mathrm{aq}}\right]$, cell size, and geometry. The authors point out, however, that "further studies are required to clearly separate the effects of growth rate, cell geometry, and $\left[\mathrm{CO}_{2, \mathrm{aq}}\right]$ on $\varepsilon_{\mathrm{p}}$." We feel that more species need to be tested to provide a larger database for calibration. Furthermore, the reported empirical relationship relies exclusively on laboratory experiments performed under nitrogen-limited conditions in continuous culture. If a regulated transport mechanism is involved in inorganic carbon acquisition, $\mu$-related variability in $\varepsilon_{\mathrm{p}}$ might depend on the factor controlling growth rate. Finally, growth rate and $\left[\mathrm{CO}_{2, \mathrm{aq}}\right]$ were manipulated simultaneously in the above-mentioned experiments so that the relative contribu- 
tion of each of these factors to changes in $\varepsilon_{\mathrm{p}}$ could not be quantified.

Our experiments were intended to: (1) determine the $\varepsilon_{\mathrm{p}}$ vs. $\mu /\left[\mathrm{CO}_{2, \text { aq }}\right]$ relationship in several species of marine microalgae; (2) avoid colimitation of algal growth by $\left[\mathrm{CO}_{2, \mathrm{aq}}\right]$ and nutrient supply or light intensity during the experiments; and (3) distinguish between the relative impact of variation in $\left[\mathrm{CO}_{2, \mathrm{aq}}\right]$ and growth rate on $\varepsilon_{\mathrm{p}}$. For that purpose, we investigated stable carbon isotope fractionation in the marine diatoms Asterionella glacialis, Thalassiosira punctigera, Coscinodiscus wailesii, Phaeodactylum tricornutum, and in the dinoflagellate Scrippsiella trochoidea under high-light, nutrient-replete conditions in dilute batch cultures. Dependence of both $\varepsilon_{\mathrm{p}}$ and $\mu$ on $\left[\mathrm{CO}_{2, \text { aq }}\right]$ in each species was evaluated at six $\mathrm{CO}_{2}$ concentrations, ranging from ca. 1 to $38 \mu \mathrm{mol} \mathrm{kg}{ }^{-1}$. In addition, the algae were cultivated under two irradiance cycles in order to vary growth rate independent of $\left[\mathrm{CO}_{2, \mathrm{aq}}\right]$ at each of the different $\mathrm{CO}_{2}$ levels. With this approach, we can separate the effect of growth rate on isotopic fractionation from $\mathrm{CO}_{2}$-related effects. Furthermore, we use our data to test the applicability of the published $\varepsilon_{\mathrm{p}}$ vs. $\mu /\left[\mathrm{CO}_{2, \text { aq }}\right]$ regressions to phytoplankton growth under nutrient-replete conditions. Finally, we consider the effect of cellular carbon content and surface area on $\varepsilon_{\mathrm{p}}$ in the five species, which covered a wide range in cell size.

The following terminology is used in this article. "Carbon supply" refers to the flux of inorganic carbon to the outer surface of an algal cell. "Carbon uptake" describes the transport of inorganic carbon through the plasmalemma into the cell, either by passive diffusion or by an active transport mechanism. "Carbon acquisition" involves both carbon uptake and subsequent transport of inorganic carbon across the chloroplast envelope to the sites of carbon fixation. Furthermore, production of extracellular carbonic anhydrase, which catalyzes the conversion of $\mathrm{HCO}_{3}^{-}$to $\mathrm{CO}_{2}$ at the outer cell surface, is regarded as a carbon acquisition mechanism. "Carbon fixation" is the incorporation of inorganic carbon into organic carbon compounds.

\section{MATERIAL AND METHODS}

With the exception of P. tricornutum (strain CCAP 1052/1A), all species tested were grown from recent isolates from the southern North Sea. In all treatments, cells were incubated at $15^{\circ} \mathrm{C}$ in $16 \mathrm{~h}: 8 \mathrm{~h}$ or $24 \mathrm{~h}: 0 \mathrm{~h}$ light/dark cycles at a photon flux density of $150 \mu \mathrm{mol}$ photons $\mathrm{m}^{-2} \mathrm{~s}^{-1}$ (400-700 nm radiation) and nutrient concentrations of $100 \mu \mathrm{mol} \mathrm{kg}^{-1}$ nitrate, $100 \mu \mathrm{mol} \mathrm{kg}{ }^{-1}$ silicate, and $6.25 \mu \mathrm{mol} \mathrm{kg}-1$ phosphate. Trace metals and vitamins were added according to $f / 2$ enrichment (Guillard and Ryther, 1962). For each species, six different $\mathrm{CO}_{2}$ concentrations between ca. 1 and $38 \mu \mathrm{mol} \mathrm{kg}^{-1}$ were adjusted by variation of $\mathrm{pH}$ between 9.1 and 7.8 upon the addition of $\mathrm{HCl}$ or $\mathrm{NaOH}$ at a constant concentration of dissolved inorganic carbon (DIC). This range in $\mathrm{pH}$ is identical to the variation in $\mathrm{pH}$ that would accompany corresponding changes in $\mathrm{CO}_{2}$ concentration in the ocean or in aerated experimental systems (e.g., Laws et al., 1995, 1997).

All experiments were performed in 2.4-L dilute batch cultures, which were typically harvested at $20-30 \mu \mathrm{mol} \mathrm{kg}^{-1}$ particulate organic carbon (POC) and never exceeded $50 \mu \mathrm{mol} \mathrm{kg}{ }^{-1}$ POC final concentration. In contrast to chemostat cultures, cells thus grew under nutrient-replete conditions at low maximum cell densities, which were of the same magnitude as can be encountered under bloom conditions in the field. In our dilute cultures, changes in $\mathrm{pH}$ during incubation were always $<0.05$ and changes in the isotopic composition of DIC never exceeded $0.4 \%$. Precision of the measurements was $\pm 1 \mu \mathrm{mol} \mathrm{kg} \mathrm{kg}^{-1}$ (DIC), $\pm 5 \mu \mathrm{eq} \mathrm{kg} \mathrm{kg}^{-1}$ (total alkalinity), $\pm 0.1 \%$ o $\left(\delta^{13} \mathrm{C}_{\mathrm{DIC}}\right), \pm 0.3 \%$ 。 $\left(\delta^{13} \mathrm{C}_{\mathrm{POC}}\right)$. For further details on methods and experimental protocol, we refer to Burkhardt et al. (1999). In the following, we briefly summarize how the key parameters relevant to our data interpretation were determined.

Concentrations of $\mathrm{CO}_{2}$ were calculated from DIC, total alkalinity, temperature, salinity, and concentrations of silicate and phosphate assuming dissociation constants of Mehrbach et al. (1973). The isotopic composition of $\mathrm{CO}_{2}\left(\delta^{13} \mathrm{C}_{\mathrm{CO}_{2}}\right)$ was determined from $\delta^{13} \mathrm{C}_{\mathrm{DIC}}$ and absolute temperature ( $\mathrm{T}_{\mathrm{k}}$, in Kelvin) according to Mook et al. (1974) by using the equation provided by Rau et al. (1996):

$$
\delta^{13} \mathrm{C}_{\mathrm{CO}_{2}}=\delta^{13} \mathrm{C}_{\mathrm{DIC}}+23.644-\frac{9701.5}{\mathrm{~T}_{\mathrm{k}}}
$$

Isotopic fractionation was calculated relative to $\mathrm{CO}_{2}$ as a carbon source according to Freeman and Hayes (1992):

$$
\varepsilon_{\mathrm{p}}=\frac{\delta^{13} \mathrm{C}_{\mathrm{CO}_{2}}-\delta^{13} \mathrm{C}_{\mathrm{POC}}}{1+\delta^{13} \mathrm{C}_{\mathrm{POC}} / 1000}
$$

The average 24-h growth rate $\mu_{\mathrm{L}+\mathrm{D}}$ was estimated from changes in concentrations of particulate organic carbon from $[\mathrm{POC}]_{\mathrm{i}}$ to $[\mathrm{POC}]_{\mathrm{i}+1}$ over the time interval $t_{\mathrm{i}}$ to $t_{\mathrm{i}+1}$ :

$$
\mu_{\mathrm{L}+\mathrm{D}}=\frac{\ln [\mathrm{POC}]_{\mathrm{i}+1}-\ln [\mathrm{POC}]_{\mathrm{i}}}{t_{\mathrm{i}+1}-t_{\mathrm{i}}}
$$

Two-point measurements of growth rates on a cellular basis between the beginning and the end of incubation were compared to daily cell counts in control bottles to examine whether a prolonged lag phase affected growth rate estimates (Burkhardt et al., 1999). No significant differences in growth rate were detected between calculation from daily cell counts and two-point measurements based on cell counts or POC measurements. Because isotopic fractionation occurs mainly by enzymatic fixation of $\mathrm{CO}_{2}$ during photosynthesis, we calculated the instantaneous rate of growth $\left(\mu_{\mathrm{i}}\right)$ from $\mu_{\mathrm{L}+\mathrm{D}}$ by accounting for the light phase (L), the dark phase (D), and dark carbon loss (r):

$$
\mu_{\mathrm{i}}=\frac{(\mathrm{L}+\mathrm{D}) \mu_{\mathrm{L}+\mathrm{D}}}{\mathrm{L}-\mathrm{Dr}}
$$

Because we did not measure dark carbon loss in our experiments, we assumed its rate to equal $15 \%$ of the rate of carbon assimilation during the preceding photoperiod (Laws and Bannister, 1980) in which case $r$ equals 0.15 in Eqn. 4.

\section{EXPERIMENTAL RESULTS}

Species-specific differences in both the dependence of $\mu_{\mathrm{i}}$ on $\left[\mathrm{CO}_{2, \mathrm{aq}}\right]$ and the relationship of $\varepsilon_{\mathrm{p}}$ with $\left[\mathrm{CO}_{2, \mathrm{aq}}\right], \mu_{\mathrm{i}}$, and $\mu_{\mathrm{i}} /\left[\mathrm{CO}_{2, \mathrm{aq}}\right]$ were found over the entire experimental $\mathrm{CO}_{2}$ range (Figs. 1 to 5). We observed a significant decrease in $\mu_{\mathrm{i}}$ at $\left[\mathrm{CO}_{2, \mathrm{aq}}\right] \leq$ ca. 3 to $6 \mu \mathrm{mol} \mathrm{kg}{ }^{-1}$ in all species except for $P$. tricornutum, which exhibited constant growth rates over the entire $\left[\mathrm{CO}_{2, \mathrm{aq}}\right]$ range from 2.1 to $38 \mu \mathrm{mol} \mathrm{kg}{ }^{-1}$. In all species, $\mu_{\mathrm{i}}$ was approximately 50 to $70 \%$ higher in a $16 \mathrm{~h}: 8 \mathrm{~h} \mathrm{~L} / \mathrm{D}$ cycle compared to growth under continuous light.

Above the $\mathrm{CO}_{2}$ threshold concentration $\mathrm{C}_{\text {lim }}$, defined as the concentration below which growth rate is $\mathrm{CO}_{2}$-dependent, isotopic fractionation increased with increasing $\left[\mathrm{CO}_{2, \mathrm{aq}}\right]$ in all species tested (Figs. 1b-5b). Only in C. wailesii did we observe little or no increase in $\varepsilon_{\mathrm{p}}$ even at the highest $\mathrm{CO}_{2}$ concentration when grown in a $16 \mathrm{~h}: 8 \mathrm{~h} \mathrm{~L} / \mathrm{D}$ cycle. Absolute values of $\varepsilon_{\mathrm{p}}$ tended to be smaller in large cells at a given $\mathrm{CO}_{2}$ concentration. In all diatoms except $P$. tricornutum, $\mathrm{CO}_{2}$-related effects on $\varepsilon_{\mathrm{p}}$ were greater when cells grew under continuous light. $S$. trochoidea was the only species in which isotopic fractionation assumed values near zero at low $\left[\mathrm{CO}_{2, \mathrm{aq}}\right]$.

At or below $\mathrm{C}_{\text {lim }}, \varepsilon_{\mathrm{p}}$ values no longer decreased with decreasing $\left[\mathrm{CO}_{2, \mathrm{aq}}\right]$ but remained constant or increased. Such a 

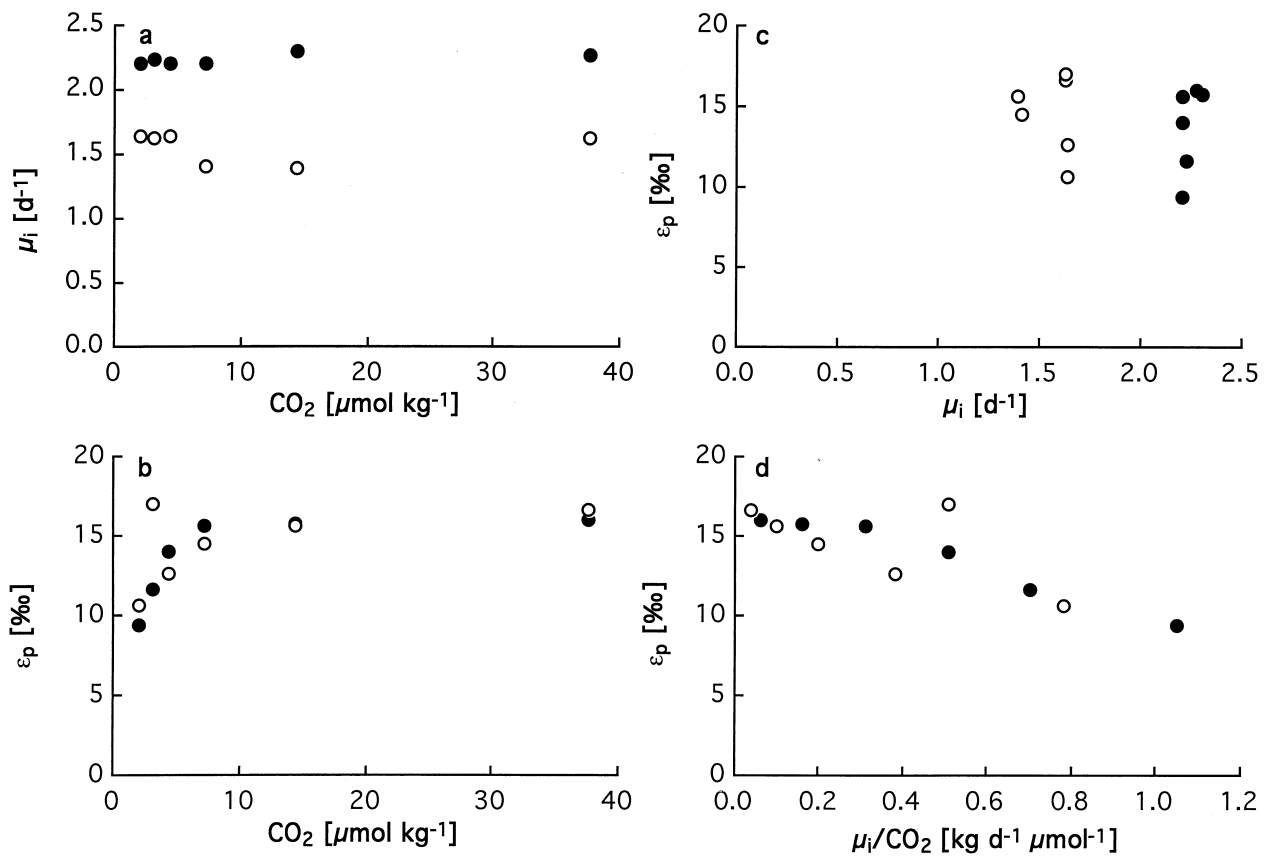

Fig. 1. Phaeodactylum tricornutum. (a) Instantaneous growth rate $\left(\mu_{\mathrm{i}}\right)$ as a function of $\left[\mathrm{CO}_{2, \text { aq }}\right]$, and stable carbon isotope fractionation as a function of (b) $\left[\mathrm{CO}_{2, \mathrm{aq}}\right]$, (c) $\mu_{\mathrm{i}}$, and (d) $\mu_{\mathrm{i}} /\left[\mathrm{CO}_{2, \mathrm{aq}}\right]$. Full symbols and open symbols represent incubation at a $16 \mathrm{~h}: 8 \mathrm{~h} \mathrm{~L} / \mathrm{D}$ cycle and continuous light, respectively.

reversal in the $\mathrm{CO}_{2}$-related $\varepsilon_{\mathrm{p}}$ trend was most pronounced in the largest species (T. punctigera and $C$. wailesii). In $P$. tricornutum, where $\mu_{\mathrm{i}}$ was independent of $\left[\mathrm{CO}_{2, \mathrm{aq}}\right]$ over the entire experimental range, $\varepsilon_{\mathrm{p}}$ continuously decreased toward the lowest $\left[\mathrm{CO}_{2, \mathrm{aq}}\right]$ in both irradiance cycles.

We observed a decrease in $\varepsilon_{\mathrm{p}}$ with increasing $\mu_{\mathrm{i}}$ in $T$.
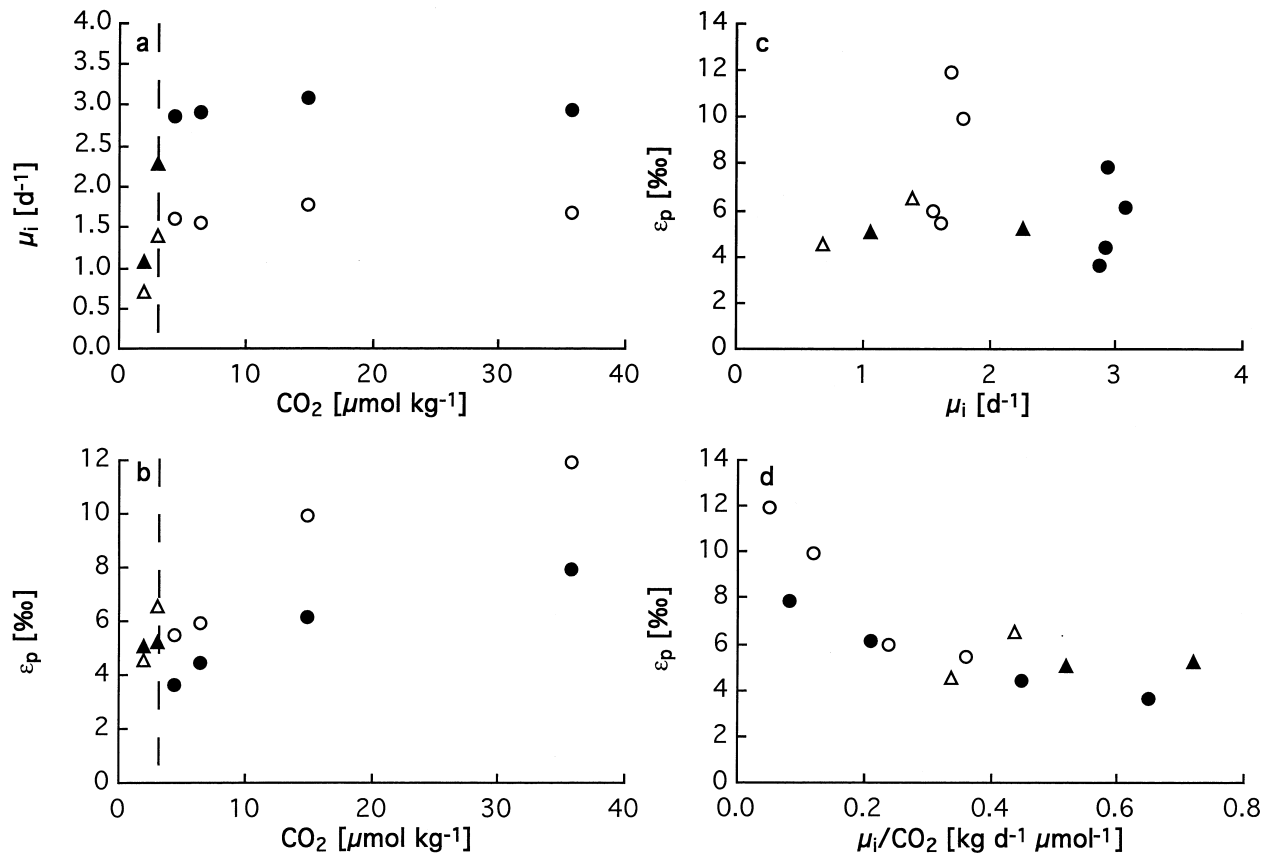

Fig. 2. Asterionella glacialis. (a) Instantaneous growth rate $\left(\mu_{\mathrm{i}}\right)$ as a function of $\left[\mathrm{CO}_{2}\right.$ ag and stable carbon isotope

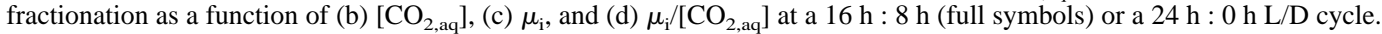
The threshold concentration $\mathrm{C}_{\text {lim }}$ at or below which $\left[\mathrm{CO}_{2, \mathrm{aq}}\right]$ affects $\mu_{\mathrm{i}}$ is indicated by the dashed line. Corresponding values of $\mu_{\mathrm{i}}$ or $\varepsilon_{\mathrm{p}}$ are indicated by triangles. 

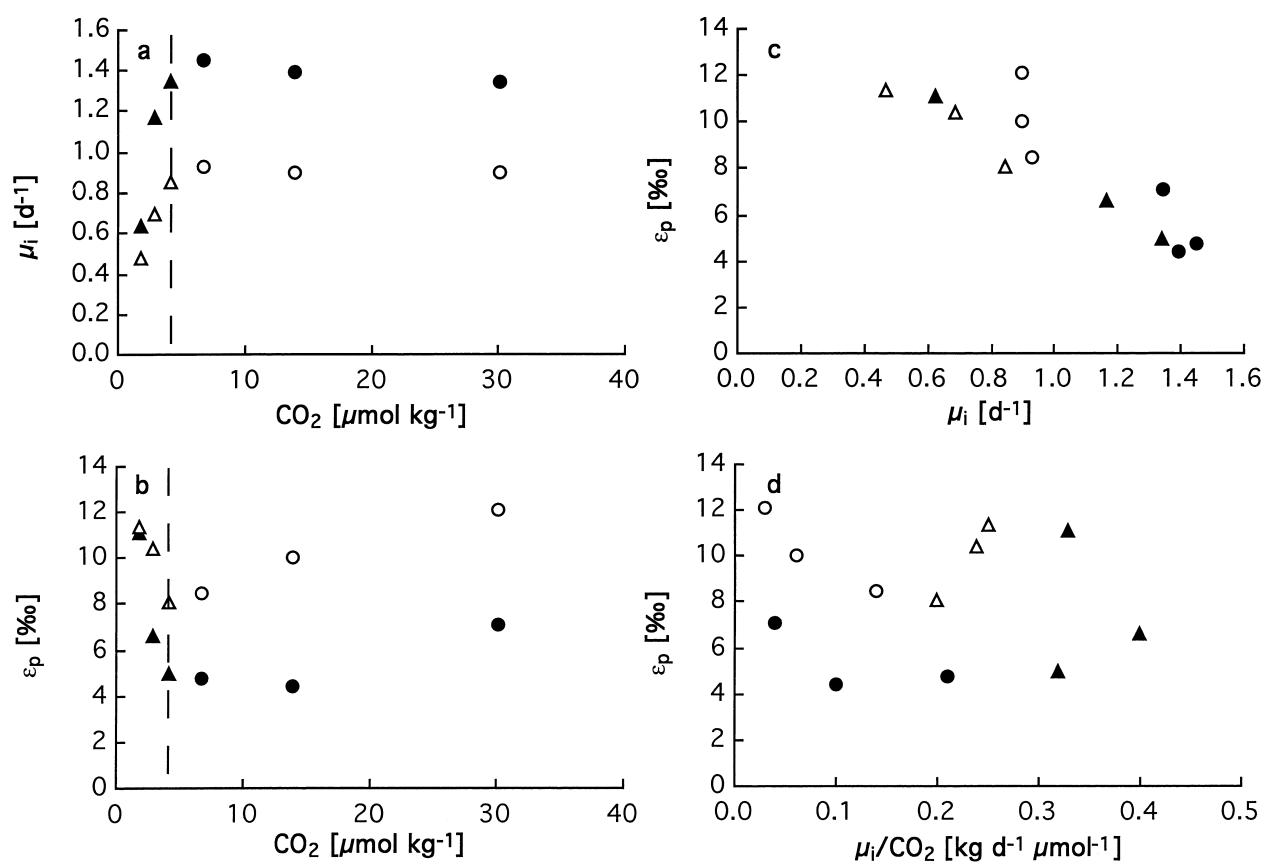

Fig. 3. Thalassiosira punctigera. (a) Instantaneous growth rate $\left(\mu_{\mathrm{i}}\right)$ as a function of $\left[\mathrm{CO}_{2, \mathrm{aq}}\right]$, and stable carbon isotope fractionation as a function of (b) $\left[\mathrm{CO}_{2, \mathrm{aq}}\right]$, (c) $\mu_{\mathrm{i}}$, and (d) $\mu_{\mathrm{i}} /\left[\mathrm{CO}_{2, \mathrm{aq}}\right]$ for two irradiance cycles. Symbols and indication of $\mathrm{C}_{\lim }$ as in Figure 2.

punctigera (Fig. 3c) and C. wailesii (Fig. 4c) without much scatter caused by an additional $\mathrm{CO}_{2}$ effect on $\varepsilon_{\mathrm{p}}$. In A. glacialis, on the other hand, the effect on $\varepsilon_{\mathrm{p}}$ caused by changes in $\mu_{\mathrm{i}}$ at different irradiance cycles is masked by the effect of $\left[\mathrm{CO}_{2, \mathrm{aq}}\right]$ (Fig. 2c). No correlation between $\varepsilon_{\mathrm{p}}$ and $\mu_{\mathrm{i}}$ was detected in $P$. tricornutum and in S. trochoidea. As indicated in Fig. 1c, $\varepsilon_{\mathrm{p}}$
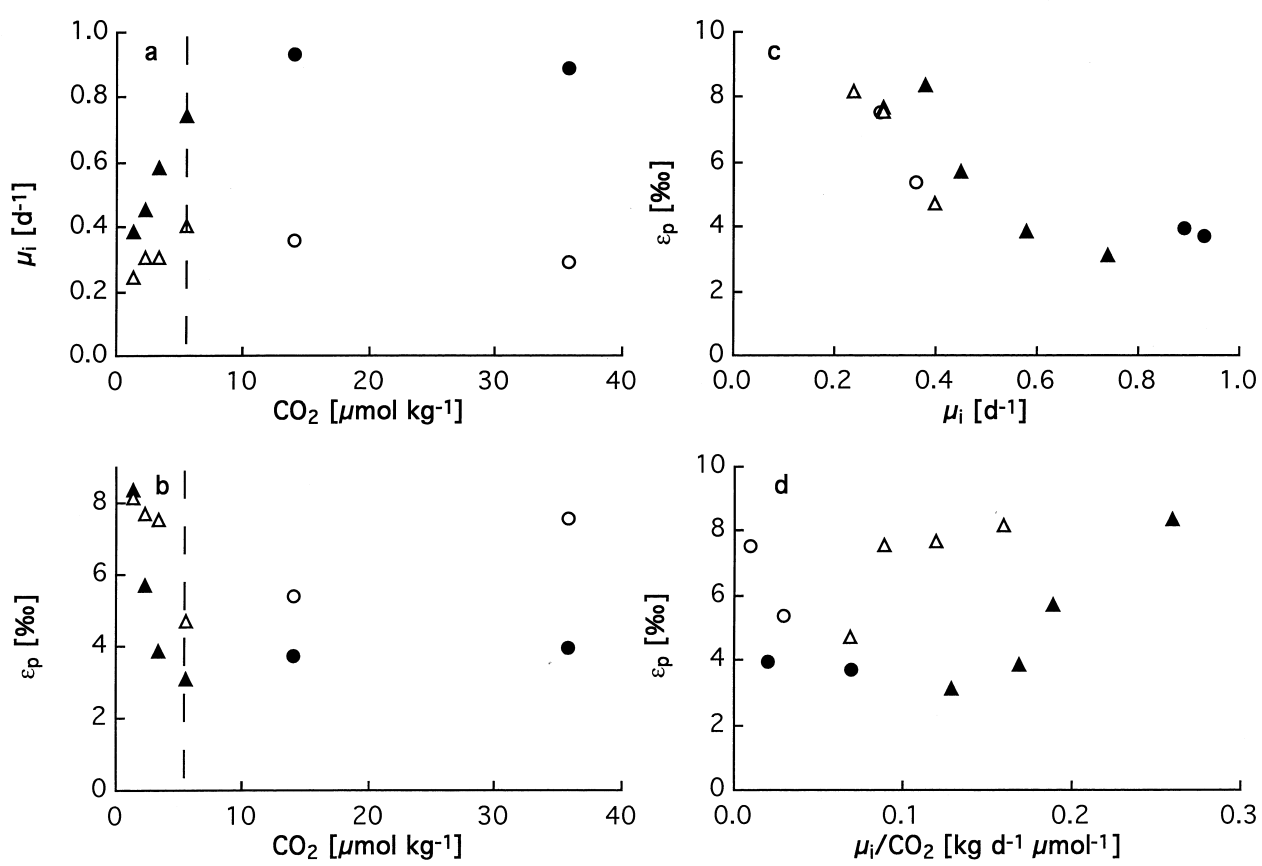

Fig. 4. Coscinodiscus wailesii. (a) Instantaneous growth rate $\left(\mu_{\mathrm{i}}\right)$ as a function of $\left[\mathrm{CO}_{2, \mathrm{aq}}\right]$, and stable carbon isotope fractionation as a function of (b) $\left[\mathrm{CO}_{2, \mathrm{aq}}\right]$, (c) $\mu_{\mathrm{i}}$, and (d) $\mu_{\mathrm{i}} /\left[\mathrm{CO}_{2, \mathrm{aq}}\right]$ for two irradiance cycles. Symbols and indication of $\mathrm{C}_{\mathrm{lim}}$ as in Figure 2. 

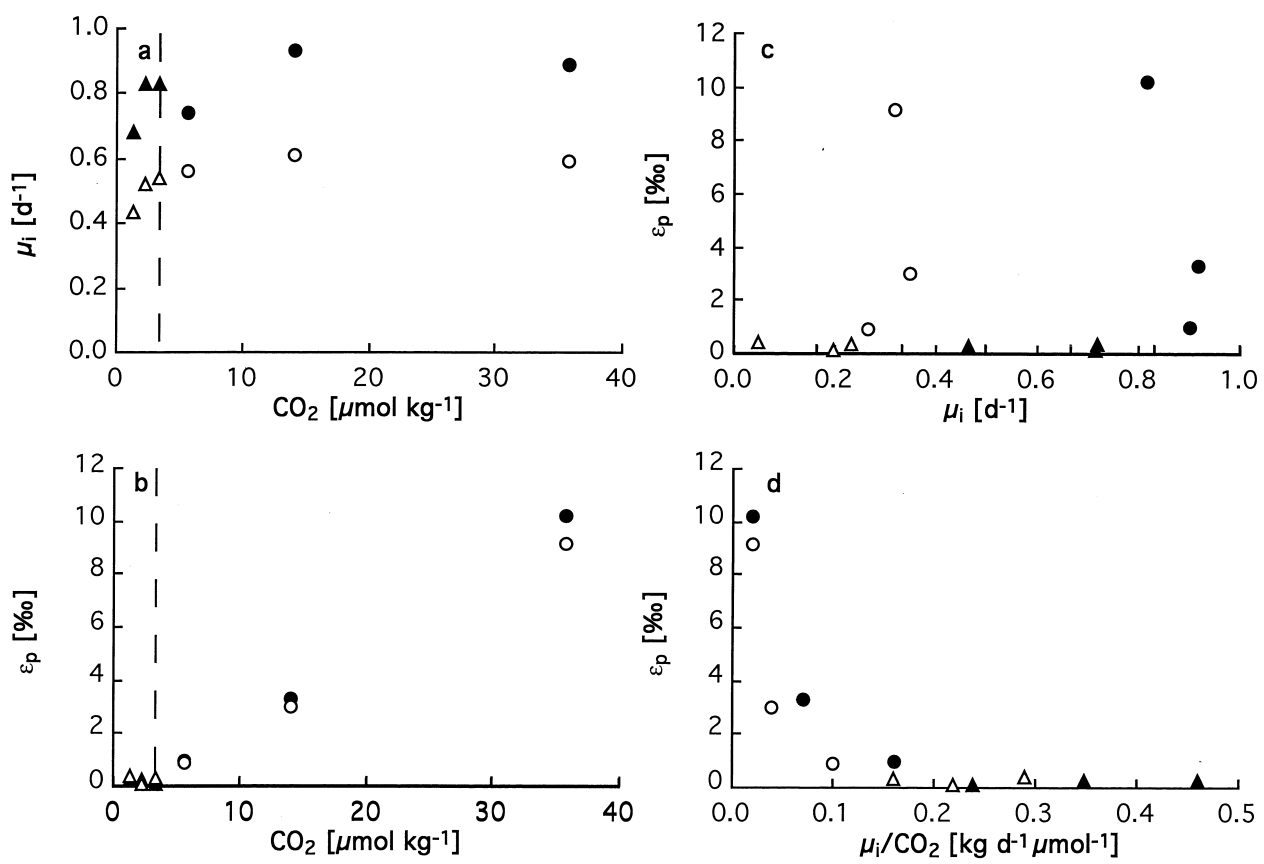

Fig. 5. Scrippsiella trochoidea. (a) Instantaneous growth rate $\left(\mu_{\mathrm{i}}\right)$ as a function of $\left[\mathrm{CO}_{2, \text { aq }}\right]$, and stable carbon isotope fractionation as a function of (b) $\left[\mathrm{CO}_{2, \mathrm{aq}}\right]$, (c) $\mu_{\mathrm{i}}$, and (d) $\mu_{\mathrm{i}} /\left[\mathrm{CO}_{2, \mathrm{aq}}\right]$ for two irradiance cycles. Symbols and indication of $\mathrm{C}_{\lim }$ as in Figure 2.

values of $P$. tricornutum range from ca. 10 to $16 \%$ in either irradiance cycle at a constant growth rate. Consequently, a relatively large residual variability $\left(r^{2}=0.714\right)$ remains in the linear correlation between $\varepsilon_{\mathrm{p}}$ and $\mu_{\mathrm{i}} /\left[\mathrm{CO}_{2, \mathrm{aq}}\right]$ in this diatom (Fig. 1d). A consistent but curvilinear decrease in $\varepsilon_{\mathrm{p}}$ with increasing $\mu_{\mathrm{i}} /\left[\mathrm{CO}_{2, \mathrm{aq}}\right]$ was found in A. glacialis (Fig. 2d) and $S$. trochoidea (Fig. 5d). No significant trend for combined data of the two irradiance cycles were observed in T. punctigera (Fig. 3d) and C. wailesii (Fig. 4d), even when $\varepsilon_{\mathrm{p}}$ values from incubations below $\mathrm{C}_{\mathrm{lim}}$ were excluded.

\section{THEORETICAL BACKGROUND}

\subsection{Fractionation as a Function of $\mathrm{C}$ Fluxes}

To provide the framework for our discussion of factors contributing to the observed variability in $\varepsilon_{\mathrm{p}}$, we first introduce a simple conceptual fractionation model. In contrast to most existing models, it permits the simultaneous uptake of both $\mathrm{CO}_{2}$ and $\mathrm{HCO}_{3}^{-}$at variable proportions. Eqn. 5 describes isotopic fractionation as a function of the carbon fluxes associated with phytoplankton carbon acquisition, where $\varepsilon_{\mathrm{p}}$ is defined as

$$
\varepsilon_{\mathrm{p}}=a\left(\varepsilon_{3}+\varepsilon_{4}\right)+(1-a) \varepsilon_{1}+\left(\varepsilon_{2}-\varepsilon_{-1}\right) \frac{\mathrm{F}_{-1}}{\mathrm{~F}_{1}+\mathrm{F}_{4}}
$$

$\mathrm{F}_{1}$ and $\mathrm{F}_{-1}$ are $\mathrm{CO}_{2}$ fluxes into and out of the cell, respectively. $\mathrm{F}_{4}$ is the flux of $\mathrm{HCO}_{3}^{-}$into the cell, and $a$ is the fractional contribution of $\mathrm{HCO}_{3}^{-}$flux to gross total carbon uptake $\left(\mathrm{F}_{\mathrm{t}}=\right.$ $\mathrm{F}_{1}+\mathrm{F}_{4}$ ) into the cell. Enzymatic fractionation during $\mathrm{C}$ fixation is denoted by $\varepsilon_{2}$; equilibrium fractionation between $\mathrm{CO}_{2}$ and $\mathrm{HCO}_{3}^{-}$is denoted by $\varepsilon_{3}$ (please note that $\varepsilon_{3}$ assumes negative values in this model). Fractionation associated with the influx and outflux of $\mathrm{CO}_{2}\left(\varepsilon_{1}, \varepsilon_{-1}\right)$ and with the uptake of $\mathrm{HCO}_{3}^{-}\left(\varepsilon_{4}\right)$ is often assumed to be on the order of ca. $1 \%$ o (Raven, 1997; Keller and Morel, 1999), which is small compared with values up to $30 \%$ fractionation by the carbon-fixing enzyme RUBISCO (Roeske and O'Leary, 1984; Guy et al., 1993 ) and $-10 \%$ for $\varepsilon_{3}$ under our experimental conditions. If we consider fractionation during inorganic carbon flux across the plasmalemma negligible, Eqn. 5 is approximated by

$$
\varepsilon_{\mathrm{p}}=a \varepsilon_{3}+\varepsilon_{2} \frac{\mathrm{F}_{-1}}{\mathrm{~F}_{\mathrm{t}}}
$$

Diffusive loss of $\mathrm{CO}_{2}$ from the cell back to the medium relative to gross total carbon uptake is termed "leakage" $\left(\mathrm{L}=\mathrm{F}_{-1} / \mathrm{F}_{\mathrm{t}}\right)$. The model does not take $\mathrm{HCO}_{3}^{-}$efflux into account, which has been suggested to constitute a significant portion of inorganic carbon loss in cyanobacteria (Salon et al., 1996). Based on mass balance considerations, $\mathrm{C}$ flux into organic carbon $\left(\mathrm{F}_{2}\right)$ during photosynthetic $\mathrm{C}$ fixation equals the difference between $\mathrm{C}$ uptake and $\mathrm{C}$ loss:

$$
\mathrm{F}_{2}=\mathrm{F}_{\mathrm{t}}-\mathrm{F}_{-1}
$$

We can describe $\mathrm{F}_{2}$ as the product of instantaneous growth rate $\left(\mu_{\mathrm{i}}\right)$ and cellular carbon content $\left(\gamma_{\mathrm{C}}\right)$, which represents the carbon-specific growth rate $\mu_{\mathrm{c}}$ :

$$
\mu_{\mathrm{c}}=\mu_{\mathrm{i}} \gamma_{\mathrm{C}}
$$

By using Eqns. 6-8, we can now define isotopic fractionation as a function of growth rate: 
Table 1. Cellular carbon content, $\gamma_{\mathrm{C}}$, and cell surface area, S. Mean $\gamma_{\mathrm{C}}( \pm 1 \mathrm{SD})$ is shown for six $\mathrm{CO}_{2}$ concentrations and two L/D cycles. Mean $\mathrm{S}( \pm 1 \mathrm{SD})$ is shown as combined data for the two L/D cycles.

\begin{tabular}{|c|c|c|c|}
\hline Species & $\begin{array}{c}\text { L/D cycle } \\
{[\mathrm{h}: \mathrm{h}]}\end{array}$ & $\begin{array}{c}\text { C/cell }\left(\gamma_{\mathrm{C}}\right) \\
{\left[\mathrm{pmol} \mathrm{cell}{ }^{-1}\right]}\end{array}$ & $\begin{array}{c}\text { Cell surface area }(\mathrm{S}) \\
{\left[\mu \mathrm{m}^{2}\right]}\end{array}$ \\
\hline P. tricornutum & $16: 8$ & $7.4( \pm 0.6) \times 10^{-1}$ & $6.9( \pm 0.2) \times 10^{1}$ \\
\hline A. glacialis & $\begin{array}{l}24: 0 \\
16: 8 \\
24: 0\end{array}$ & $\begin{array}{l}7.6( \pm 0.6) \times 10^{-1} \\
9.7( \pm 0.6) \times 10^{0} \\
79(+0.7) \times 10^{0}\end{array}$ & $4.1( \pm 0.3) \times 10^{2}$ \\
\hline T. punctigera & $\begin{array}{l}16: 8 \\
24: 0\end{array}$ & $\begin{array}{l}1.8( \pm 0.1) \times 10^{2} \\
1.5( \pm 0.1) \times 10^{2}\end{array}$ & $5.8( \pm 0.4) \times 10^{3}$ \\
\hline C. wailesii & $\begin{array}{l}16: 8 \\
24: 0\end{array}$ & $\begin{array}{l}3.6( \pm 0.2) \times 10^{4} \\
3.8( \pm 0.3) \times 10^{4}\end{array}$ & $1.1( \pm 0.3) \times 10^{5}$ \\
\hline S. trochoidea & $\begin{array}{l}16: 8 \\
24: 0\end{array}$ & $\begin{array}{l}5.9( \pm 0.8) \times 10^{1} \\
5.4( \pm 0.4) \times 10^{1}\end{array}$ & $3.3( \pm 0.3) \times 10^{3}$ \\
\hline
\end{tabular}

$$
\varepsilon_{\mathrm{p}}=a \varepsilon_{3}+\varepsilon_{2}-\varepsilon_{2} \frac{\mu_{\mathrm{c}}}{\mathrm{F}_{\mathrm{t}}}
$$

This general formulation accounts for carbon uptake of $\mathrm{CO}_{2}$ and/or $\mathrm{HCO}_{3}^{-}$irrespective of the mechanism by which inorganic carbon passes the membrane. $\mathrm{CO}_{2}$ may enter the cell by passive diffusion or active transport. Due to the low permeability of biological membranes for the charged molecule $\mathrm{HCO}_{3}^{-}$, it is usually assumed that $\mathrm{HCO}_{3}^{-}$can enter an algal cell only by an energy-dependent uptake mechanism (see Raven, 1997, for review) and that inorganic carbon leaves the cell only by passive diffusion of $\mathrm{CO}_{2}$. Further assumptions made in this model are that: (1) the cell consists of a single compartment; (2) fractionation associated with $\mathrm{C}$ loss due to respiration or photorespiration is negligible; and (3) all $\mathrm{HCO}_{3}^{-}$entering the cell is converted into $\mathrm{CO}_{2}$ before it becomes fixed into organic $\mathrm{C}$ compounds or is lost from the cell (i.e., no fractionation is associated with this reaction). If all inorganic carbon is taken up as $\mathrm{CO}_{2}\left(a=0, \mathrm{~F}_{\mathrm{t}}=\mathrm{F}_{1}\right)$ and fractionation associated with carbon flux across the plasmalemma is considered negligible $\left(\varepsilon_{1}, \varepsilon_{-1}=0\right)$, the model is identical with the fractionation models suggested by Francois et al. (1993) and Laws et al. (1995). If all inorganic carbon is taken up by active transport of $\mathrm{HCO}_{3}^{-}\left(a=1, \mathrm{~F}_{\mathrm{t}}=\mathrm{F}_{4}\right)$ and no fractionation occurs during $\mathrm{C}$ flux across the plasmalemma $\left(\varepsilon_{4}, \varepsilon_{-1}=0\right)$, the model is identical with the carbon concentrating model suggested by Sharkey and Berry (1985).

Precise measurements of fractionation during $\mathrm{C}$ fixation $\left(\varepsilon_{2}\right)$ are not available for eukaryotic microalgae. For the carbonfixing enzyme RUBISCO, isolated from spinach, Roeske and O'Leary (1984) report $\varepsilon_{2}$ values of $30 \%$ ( $\left.\mathrm{pH} 7.0\right), 29 \%$ (pH $8.0)$, and $26 \%$ ( $\mathrm{pH} 9.0)$, which is similar to $\varepsilon_{2}=30.3 \% \circ(\mathrm{pH}$ 8.5 ) determined by Guy et al. (1993). Thus, the effect of $\mathrm{pH}$ on $\varepsilon_{2}$ is small and is probably negligible in vivo (Guy et al., 1993), if we consider maintenance of relatively constant $\mathrm{pH}$ levels inside the chloroplast, where RUBISCO is located.

In contrast to higher $\mathrm{C}_{3}$ plants such as spinach, fractionation by RUBISCO is significantly lower in a photosynthetic bacterium and a cyanobacterium, with $\varepsilon_{2}$ values ranging between 17.8 and $23.0 \%$ depending on species and reaction conditions (Roeske and O'Leary, 1985; Guy et al., 1993). A comparison of kinetic and structural properties of RUBISCO (see Raven, 1997 and Badger et al., 1998, for recent reviews) suggests that $\varepsilon_{2}$ values of diatoms show greater similarity with higher $\mathrm{C}_{3}$ plants than with the low fractionation of photosynthetic bacteria. Direct evidence for high fractionation during carboxylation reactions in marine diatoms is given by direct measurements of $\varepsilon_{\mathrm{p}}=26 \%$ in $P$. tricornutum (Laws et al., 1997; U.R., unpubl. data) at low $\mu /\left[\mathrm{CO}_{2, \mathrm{aq}}\right]$, which implies $\varepsilon_{2} \geq 26 \%$. For the interpretation of our results, we thus adopted a constant $\varepsilon_{2}$ value of $27 \%$ o. This represents the mid-point of the range for maximum fractionation by all cellular carboxylation reactions (25.4-28.3\%o) suggested by Goericke et al. (1994), which also accounts for fractionation by $\beta$-carboxylation.

If we assume that $\varepsilon_{2}$ does not differ between species and treatments, isotopic fractionation is only a function of growth rate relative to gross total $\mathrm{C}$ uptake, and of the relative contribution of $\mathrm{HCO}_{3}^{-}$to the flux of inorganic carbon into the cell (Eqn. 9), because $\varepsilon_{3}$ was constant in our experiments. Instantaneous growth rates of each species were approximately proportional to carbon-specific growth rates, as cellular carbon content exhibited no systematic trend over the experimental $\mathrm{CO}_{2}$ range and differences in $\gamma_{\mathrm{C}}$ between irradiance cycles were small (Table 1).

\subsection{Minimum $\left[\mathrm{CO}_{2, \mathrm{aq}}\right]$ for Diffusive $\mathrm{C}$ Uptake}

The fractionation model provides a tool to estimate the minimum $\mathrm{CO}_{2}$ concentration at which the uncatalyzed diffusive supply of carbon dioxide to the cell surface is sufficient to account for the observed rate of gross carbon uptake. Diffusive flux of $\mathrm{CO}_{2}$ to an algal cell $\left(\mathrm{F}_{\mathrm{r}}\right)$ can be calculated as

$$
\mathrm{F}_{\mathrm{r}}=4 \pi \mathrm{rD}\left(1+\frac{\mathrm{r}_{\mathrm{s}}}{\mathrm{r}_{\mathrm{k}}}\right)\left(\left[\mathrm{CO}_{2, \mathrm{aq}}\right]-\mathrm{C}_{\mathrm{r}}\right)
$$

where $r_{s}$ is the surface-equivalent spherical cell radius, $D$ is the diffusion coefficient for $\mathrm{CO}_{2}$ in the medium, $\mathrm{r}_{\mathrm{k}}$ is the reactodiffusive length, and $\mathrm{C}_{\mathrm{r}}$ is the $\mathrm{CO}_{2}$ concentration at the cell surface (Riebesell et al., 1993; Wolf-Gladrow and Riebesell, 1997). Maximum $\mathrm{CO}_{2}$ flux to an algal cell can theoretically be achieved if $\mathrm{C}_{\mathrm{r}}$ approaches 0 due to algal carbon uptake, corresponding to the maximum $\mathrm{CO}_{2}$ gradient between the bulk medium and the cell surface. If we set $\mathrm{C}_{\mathrm{r}}=0$ and maximum $\mathrm{F}_{\mathrm{r}}=\mathrm{F}_{1}$, we can then calculate the minimum $\mathrm{CO}_{2}$ concentration $\left(\mathrm{CO}_{2, \text { min }}\right)$ required to satisfy $\mathrm{C}$ flux into the cell by passive diffusion according to 


$$
\mathrm{CO}_{2, \min }=\frac{\mathrm{F}_{1}}{4 \pi \mathrm{rD}\left(1+\mathrm{r} / \mathrm{r}_{\mathrm{k}}\right)}
$$

The value for $F_{1}$ is obtained from Eqn. 9 based on measurements of $\varepsilon_{\mathrm{p}}, \mu_{\mathrm{i}}$, and cellular carbon content, assuming $\varepsilon_{2}=$ $27 \%$ and diffusive $\mathrm{CO}_{2}$ uptake to be the only carbon source for photosynthesis (i.e., $a=0, \mathrm{~F}_{\mathrm{t}}=\mathrm{F}_{1}$ ). The term $1+\mathrm{r}_{\mathrm{s}} / \mathrm{r}_{\mathrm{k}}$ accounts for the contribution of extracellular uncatalyzed $\mathrm{HCO}_{3}^{-}-\mathrm{CO}_{2}$ conversion to total $\mathrm{CO}_{2}$ supply and was calculated according to Wolf-Gladrow and Riebesell (1997). $\mathrm{A} \mathrm{CO}_{2}$ diffusion coefficient of $\mathrm{D}=1.45 \times 10^{-9} \mathrm{~m}^{2} \mathrm{~s}^{-1}$ at $15^{\circ} \mathrm{C}$ (Rau et al., 1996) was used for all calculations of $\mathrm{CO}_{2 \text {, min }}$.

\section{DISCUSSION}

A central aspect for the interpretation of stable carbon isotope fractionation is the mechanism of inorganic carbon acquisition in marine phytoplankton. In the case that cellular carbon uptake is dominated by passive diffusion of $\mathrm{CO}_{2}$ across the plasmalemma, any change in $\left[\mathrm{CO}_{2, \text { aq }}\right]$ directly affects the flux of inorganic carbon into the cell. Below a critical $\mathrm{CO}_{2}$ concentration, diminishing $\mathrm{CO}_{2}$ supply leads to a decrease in growth rate. Under these conditions, a simple linear relationship between isotopic fractionation and $\mu /\left[\mathrm{CO}_{2, \mathrm{aq}}\right]$ is predicted from fractionation models (e.g., Francois et al., 1993; Goericke et al., 1994; Laws et al., 1995; Rau et al., 1996).

Catalyzed conversion of $\mathrm{HCO}_{3}^{-}$to $\mathrm{CO}_{2}$ by extracellular carbonic anhydrase (CA) may significantly accelerate the rate of $\mathrm{CO}_{2}$ supply to the cell surface. Isotopic fractionation in this scenario may be indistinguishable from $\mathrm{CO}_{2}$ uptake in the absence of CA (Riebesell and Wolf-Gladrow, 1995). However, the correlation between $\varepsilon_{\mathrm{p}}$ and bulk $\left[\mathrm{CO}_{2, \mathrm{aq}}\right]$ is less predictable if the $\mathrm{CO}_{2}$ concentration near the cell surface is not only a function of $\left[\mathrm{CO}_{2, \mathrm{aq}}\right]$ but also of $\mathrm{CA}$ activity.

Active uptake of inorganic carbon adds further complexity to the interpretation of isotope data. Energy-dependent uptake of both $\mathrm{CO}_{2}$ and/or $\mathrm{HCO}_{3}^{-}$has been suggested in several microalgae (for recent reviews, see Raven, 1997; Kaplan and Reinhold, 1999). Compared to $\mathrm{CO}_{2}$ uptake, the transport of $\mathrm{HCO}_{3}^{-}$ through the plasmalemma alters the isotopic composition of the inorganic carbon pool inside the cell, which translates into a change in $\varepsilon_{\mathrm{p}}$. If $\mathrm{HCO}_{3}^{-}$is taken up directly from the medium, growth rate becomes independent of extracellular $\mathrm{CO}_{2}$ concentrations. Regardless of the carbon species entering the cell, regulated active $\mathrm{C}$ transport can affect the ratio of $\mathrm{C}$ uptake to growth rate, which is a critical parameter in isotopic fractionation.

In the following, we discuss our experimental results with respect to different carbon acquisition scenarios. We apply several criteria to evaluate the possibility of diffusive $\mathrm{CO}_{2}$ uptake and consider the potential consequences of active carbon transport for the interpretation of isotope data.

\subsection{Diffusive vs. Active Carbon Uptake}

To distinguish between uncatalyzed diffusive $\mathrm{CO}_{2}$ uptake and CA-mediated $\mathrm{HCO}_{3}^{-}$utilization or active uptake of inorganic carbon in our experiments, we considered the following parameters: the critical $\mathrm{CO}_{2}$ concentration $\left(\mathrm{C}_{\text {min }}\right)$ below which cellular $\mathrm{C}$ demand cannot be satisfied by passive diffusion alone, the daylength-related variability in $\varepsilon_{\mathrm{p}}$ at constant
$\left[\mathrm{CO}_{2, \mathrm{aq}}\right]$, and the linearity of the relationship between $\varepsilon_{\mathrm{p}}$ and $\mu_{\mathrm{i}} /\left[\mathrm{CO}_{2, \mathrm{aq}}\right]$.

In most species and treatments, bulk concentrations of $\mathrm{CO}_{2}$ were several-fold higher than the minimum $\mathrm{CO}_{2}$ concentration required for diffusive $\mathrm{CO}_{2}$ uptake (Fig. 6). These results indicate that most species were theoretically able to satisfy their cellular carbon demand at all experimental $\mathrm{CO}_{2}$ levels by diffusive $\mathrm{CO}_{2}$ uptake even in the absence of extracellular CA. In contrast to the smaller species, $\mathrm{CO}_{2 \text {,min }}$ of $C$ wailesii was one order of magnitude higher and exceeded $\left[\mathrm{CO}_{2, \text { aq }}\right]$ in all treatments. These cells require an additional carbon source, either by the CA-catalyzed conversion of $\mathrm{HCO}_{3}^{-}$to $\mathrm{CO}_{2}$ near the cell surface with subsequent $\mathrm{CO}_{2}$ uptake, or by direct transport of $\mathrm{HCO}_{3}^{-}$through the plasmalemma. Similarly, extracellular CA activity or direct $\mathrm{HCO}_{3}^{-}$uptake is necessary to account for the carbon demand of T. punctigera at $\left[\mathrm{CO}_{2, \mathrm{aq}}\right]<$ $5 \mu \mathrm{mol} \mathrm{kg}{ }^{-1}$ in this study.

According to the diffusion model, any change in growth rate at a given $\mathrm{CO}_{2}$ concentration should be reflected in variable $\varepsilon_{\mathrm{p}}$. In $P$. tricornutum and in $S$. trochoidea, isotopic fractionation was unaffected by daylength at each $\left[\mathrm{CO}_{2, \mathrm{aq}}\right]$ despite significant differences in $\mu_{\mathrm{i}}$. We take this as evidence for a regulated carbon acquisition mechanism in these species even at the highest experimental $\mathrm{CO}_{2}$ concentration. In the other three species, daylength-related differences in $\varepsilon_{\mathrm{p}}$ are consistent with uncatalyzed diffusive $\mathrm{CO}_{2}$ uptake, but do not exclude the possibility of extracellular CA activity or active carbon transport.

Another prediction by the diffusion model is a linear, inverse relationship between $\varepsilon_{\mathrm{p}}$ and $\mu_{\mathrm{i}} /\left[\mathrm{CO}_{2, \mathrm{aq}}\right]$ with $\varepsilon_{\mathrm{p}}$ close to enzymatic fractionation as $\mu_{\mathrm{i}} /\left[\mathrm{CO}_{2, \mathrm{aq}}\right]$ approaches 0 . In four of the species tested, the lack of such a linear correlation suggests that mechanisms other than uncatalyzed passive diffusion are involved in carbon acquisition of these species. The relatively large scatter in the $\varepsilon_{\mathrm{p}}$ vs. $\mu_{\mathrm{i}} /\left[\mathrm{CO}_{2, \text { aq }}\right]$ relationship of $P$. tricornutum may also result from regulated $\mathrm{C}$ uptake. Furthermore, the $y$-intercept of the corresponding regression line in this species is approximately $17 \%$, which is far below the expected value of 25-28\%o (Raven and Johnston, 1991; Goericke et al., 1994) in the case of diffusive $\mathrm{CO}_{2}$ uptake.

\section{2. $\mathrm{CO}_{2}$ vs. $\mathrm{HCO}_{3}^{-}$Uptake}

We applied three criteria to extract information from our experimental data regarding the carbon species entering the cell: $\mathrm{CO}_{2}$-related variability in $\varepsilon_{\mathrm{p}}$ at a constant growth rate, simultaneous changes in $\varepsilon_{\mathrm{p}}$ and growth rate at variable $\left[\mathrm{CO}_{2, \mathrm{aq}}\right]$, and maximum fractionation achieved at the highest $\mathrm{CO}_{2}$ concentration.

In all species tested, growth rate was largely independent of $\left[\mathrm{CO}_{2, \mathrm{aq}}\right]$ over a wide range of $\mathrm{CO}_{2}$ concentrations, whereas $\varepsilon_{\mathrm{p}}$ decreased towards lower $\left[\mathrm{CO}_{2, \text { aq }}\right]$ in this range. It is unlikely that direct uptake of $\mathrm{HCO}_{3}^{-}$as the only carbon source can account for the observed pattern, because fractionation is expected to remain constant in that case. Two different scenarios, however, could explain the data.

In the first scenario, $\mathrm{CO}_{2}$ is the dominant carbon species entering the cell, either by passive diffusion (possibly in combination with extracellular CA activity) or by active transport of $\mathrm{CO}_{2}$. If a decrease in $\left[\mathrm{CO}_{2, \mathrm{aq}}\right]$ results in diminishing $\mathrm{CO}_{2}$ 


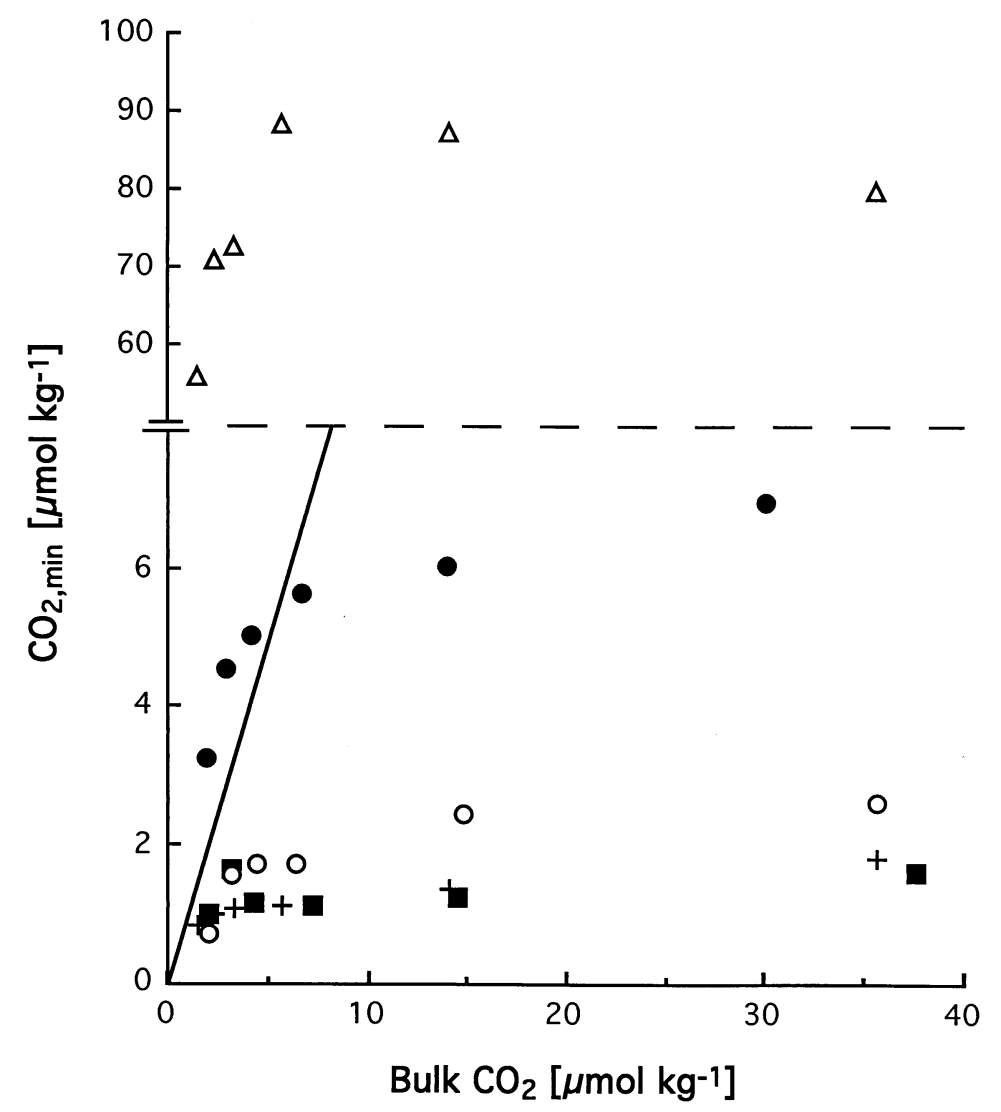

Fig. 6. Minimum $\mathrm{CO}_{2}$ concentration $\left(\mathrm{C}_{\text {min }}\right)$ required for diffusive $\mathrm{CO}_{2}$ uptake as a function of bulk $\left[\mathrm{CO}_{2, \text { aq }}\right]$. $\mathrm{C}_{\min }$ was calculated for $P$. tricornutum $(\mathbf{\square})$, A. glacialis $(\bigcirc)$, . punctigera $(\bullet), C$. wailesii $(\triangle)$, and $S$. trochoidea $(+)$ during growth under continuous light. The reference line indicates $\mathrm{C}_{\min }=\left[\mathrm{CO}_{2, \text { aq }}\right]$. Above this line, uncatalyzed diffusive $\mathrm{CO}_{2}$ supply is insufficient to account for algal $\mathrm{C}$ uptake. Please note differences in scale on the y-axis. $\mathrm{C}_{\min }$ in $C$. wailesii is approximately one order of magnitude higher than in the smaller species.

uptake rates $\left(\mathrm{F}_{1}\right), \varepsilon_{\mathrm{p}}$ decreases due to an increase in the ratio $\mu_{\mathrm{i}} / \mathrm{F}_{1}$ as long as the carbon supply is high enough to maintain a constant growth rate. An algal cell may possess several options to achieve such an increase in $\mathrm{C}$ assimilation efficiency (i.e., reduce leakage of $\mathrm{CO}_{2}$ ), as will be discussed below.

Alternatively, the decrease in $\varepsilon_{\mathrm{p}}$ toward lower $\mathrm{CO}_{2}$ concentrations may result from the gradual induction of $\mathrm{HCO}_{3}^{-}$transport across the plasmalemma in addition to $\mathrm{CO}_{2}$ uptake. In this scenario, the cell is able to maintain a constant rate of gross $\mathrm{C}$ uptake. The apparent shift in $\varepsilon_{\mathrm{p}}$ results from the higher fractional contribution of $\mathrm{HCO}_{3}^{-}$to total $\mathrm{C}$ flux into the cell at lower $\left[\mathrm{CO}_{2, \mathrm{aq}}\right]$.

Regardless of the differences between the two scenarios, a significant contribution of $\mathrm{CO}_{2}$ to total carbon uptake is a prerequisite in both cases to account for the $\mathrm{CO}_{2}$-related changes in $\varepsilon_{\mathrm{p}}$ at a constant growth rate in this study.

With the exception of $P$. tricornutum, growth rate declined in all species below a critical $\mathrm{CO}_{2}$ concentration $\left(\mathrm{C}_{\mathrm{lim}}\right)$. In this $\mathrm{CO}_{2}$ range, isotopic fractionation did not further decrease but even increased upon a decline in $\left[\mathrm{CO}_{2, \mathrm{aq}}\right]$. If the cells can take up $\mathrm{HCO}_{3}^{-}$directly from the medium, neither a $\mathrm{CO}_{2}$-related decline in growth rate nor a corresponding increase in $\varepsilon_{\mathrm{p}}$ would be expected. On the other hand, the observed pattern is consistent with $\mathrm{CO}_{2}$ transport into the cell: at $\left[\mathrm{CO}_{2, \mathrm{aq}}\right]<\mathrm{C}_{\text {lim }}$, any increase in $\varepsilon_{\mathrm{p}}$ towards lower $\mathrm{CO}_{2}$ concentrations requires that a decrease in the carbon uptake rate is accompanied by an even larger decline in growth rate. Calculations according to Eqn. 9 (assuming $a=0, \varepsilon_{2}=27 \%$ ) indicate that the measured decrease in $\mu_{\mathrm{i}}$ by $53 \%$ (T. punctigera) and $49 \%$ (C. wailesii) leads to the observed increase in $\varepsilon_{\mathrm{p}}$ if $\mathrm{F}_{1}$ declines by $35 \%$ or $34 \%$, respectively.

Such a decline in $\mathrm{C}$ assimilation efficiency (i.e., a decrease in $\left.\mu_{\mathrm{i}} / \mathrm{F}_{1}\right)$ towards lower $\left[\mathrm{CO}_{2, \mathrm{aq}}\right]$ is expected for several reasons. First, the probability of diffusive $\mathrm{CO}_{2}$ loss from the cell back into the medium increases with diminishing $\left[\mathrm{CO}_{2, \mathrm{aq}}\right]$, so that a smaller fraction of gross total carbon uptake is available for cellular growth. Second, it is reasonable to assume that the carbon-fixing enzyme RUBISCO shows nonlinear saturation kinetics. Therefore, a decline in substrate (i.e., $\mathrm{CO}_{2}$ ) concentration in response to diminishing carbon uptake rates is likely to result in an unproportionally stronger decline in the rate of $\mathrm{CO}_{2}$ fixation. Third, in the case of active $\mathrm{CO}_{2}$ uptake, the ratio of $\mathrm{C}$ uptake to $\mathrm{C}$ fixation can be affected by the availability of energy (ATP) and reducing power $\left(\mathrm{NADPH}_{2}\right)$ at low $\left[\mathrm{CO}_{2, \mathrm{aq}}\right]$. Under high-light and nutrient-replete conditions, yet at low $\left[\mathrm{CO}_{2, \mathrm{aq}}\right]$, substrate limitation of $\mathrm{CO}_{2}$ fixation in the Calvin cycle decreases the demand for both ATP and $\mathrm{NADPH}_{2}$, which results in the accumulation of electrons in the light-dependent 
photosynthesis reactions. Pseudocyclic electron flow (Mehler reaction), which ultimately leads to the reduction of oxygen within the cell, may serve as an electron sink to dissipate excess light energy (Sültemeyer et al., 1993; Kaplan and Reinhold, 1999). Because the Mehler reaction generates additional ATP (but not $\mathrm{NADPH}_{2}$ ), active $\mathrm{CO}_{2}$ transport (which requires energy but not reducing power) may be less affected by diminishing $\mathrm{CO}_{2}$ supply than by the rate of carbon fixation.

Another potential tool to distinguish between $\mathrm{CO}_{2}$ and $\mathrm{HCO}_{3}^{-}$uptake is the maximum fractionation achieved by a cell. Isotopic fractionation cannot exceed maximum fractionation in carboxylation reactions, which has been suggested to lie in the range of 25.4-28.3\%o (Goericke et al., 1994). Direct measurements of $\varepsilon_{\mathrm{p}}$ in $P$. tricornutum revealed values up to $25.72 \%$ o (Laws et al., 1997) at $\left[\mathrm{CO}_{2, \mathrm{aq}}\right]=34.7 \mu \mathrm{mol} \mathrm{kg}^{-1}$ and $\mu_{\mathrm{i}}=0.5$ $\mathrm{d}^{-1}$. Such high $\varepsilon_{\mathrm{p}}$ values cannot be obtained by $\mathrm{HCO}_{3}^{-}$uptake. In fact, even in the case of exclusive $\mathrm{CO}_{2}$ uptake, approximately $90 \%$ leakage (diffusive loss of $\mathrm{CO}_{2}$ back to the medium) is required to account for the observed fractionation when $\varepsilon_{2}=28.3 \%$ is assumed (Eqn. 6).

At a similar $\mathrm{CO}_{2}$ concentration in our study, $\varepsilon_{\mathrm{p}}$ was approximately $10 \%$ o lower. A comparison with the $\varepsilon_{\mathrm{p}}$ vs. $\mu_{\mathrm{i}} /\left[\mathrm{CO}_{2, \mathrm{aq}}\right]$ relationship of Laws et al. (1995) indicates that the higher growth rate in our experiments (L/D 24:0, $\mu_{\mathrm{i}}=1.63 \mathrm{~d}^{-1}$, $\left[\mathrm{CO}_{2, \mathrm{aq}}\right]=37.7 \mu \mathrm{mol} \mathrm{kg}{ }^{-1}$ ) would account for approximately half of the difference in $\varepsilon_{\mathrm{p}}$ between the two studies. Alternatively, differences in the kind of growth limitation may account for much of the observed difference in $\varepsilon_{\mathrm{p}}$. A potential effect of $\mathrm{N}$ limitation on isotopic fractionation has been suggested by Kukert and Riebesell (1998) for field data and by Riebesell et al. (submitted). In the latter study, fractionation of P. tricornutum at different light intensities and $\left[\mathrm{CO}_{2, \mathrm{aq}}\right]$ was compared with results for this species reported by Johnston (1996), Laws et al. (1997), and in this article. A comparison of recent data by Riebesell (unpublished) with those of Bidigare et al. (1997), using the same strain of the coccolithophorid E. huxleyi, is consistent with the suggestion that $\mathrm{N}$ limitation yields higher $\varepsilon_{\mathrm{p}}$ at similar growth rates and $\left[\mathrm{CO}_{2, \mathrm{aq}}\right]$.

Although isotopic fractionation of $P$. tricornutum in this study did not exceed $16.7 \%$, this value still provides evidence that $\mathrm{HCO}_{3}^{-}$uptake did not dominate inorganic carbon flux into the cell. According to Eqns. 6 and 9, 90\% leakage is required to achieve $16.7 \%$ o fractionation in the case of $\mathrm{HCO}_{3}^{-}$uptake. This is highly unlikely from an energetic point of view, because metabolic energy is spent for each $\mathrm{HCO}_{3}^{-}$molecule entering the cell. Calculated leakage values are lower by approximately $40 \%$ in case that $\mathrm{CO}_{2}$ is the only carbon species passing the plasmalemma. It should be pointed out that these calculations are based on the assumption that inorganic carbon loss from the cell occurs only as $\mathrm{CO}_{2}$. Different results would be obtained if significant amounts of $\mathrm{HCO}_{3}^{-}$can leave the cell, possibly by $\mathrm{HCO}_{3}^{-}: \mathrm{HCO}_{3}^{-}$exchange.

In all species, maximum fractionation was ca. 8 to $17 \%$, i.e., significantly lower than fractionation during carboxylation reactions. Higher values are expected upon a further increase in $\mathrm{CO}_{2}$ concentration beyond the experimental range of our study. Due to the lack of a linear relationship between $\varepsilon_{\mathrm{p}}$ and $\mu /\left[\mathrm{CO}_{2, \mathrm{aq}}\right]$, this kind of analysis cannot be used to infer maximum $\varepsilon_{\mathrm{p}}$ values for the respective species from our data.
Nonlinear fits should be treated with caution until a mechanistic explanation for the variability in $\varepsilon_{\mathrm{p}}$ is established.

At this point in our discussion, we may conclude that $\mathrm{CO}_{2}$ flux into the cell appears to constitute a significant portion of gross total carbon uptake in all species tested. Several lines of evidence, however, indicate that either active $\mathrm{C}$ transport and/or the activity of extracellular CA are required to account for the observed correlation of $\varepsilon_{\mathrm{p}}$ with $\left[\mathrm{CO}_{2, \mathrm{aq}}\right]$ and growth rate. With the exception of $P$. tricornutum, a critical $\mathrm{CO}_{2}$ concentration has been observed in all species, below which the cells are not able to maintain a constant growth rate. Even if these organisms possess a mechanism for direct uptake of $\mathrm{HCO}_{3}^{-}$, it is insufficient to compensate for the diminishing $\mathrm{CO}_{2}$ supply. In experiments with $P$. tricornutum, the lowest experimental $\left[\mathrm{CO}_{2, \text { aq }}\right]$ was $2.1 \mu \mathrm{mol} \mathrm{kg}{ }^{-1}$. It could be that the critical $\mathrm{CO}_{2}$ level for $\mathrm{C}$-limited growth is reached at an even lower $\mathrm{CO}_{2}$ concentration due to the small cell size of this species. This could be tested in further experiments at $\left[\mathrm{CO}_{2, \mathrm{aq}}\right]$ $<2 \mu \mathrm{mol} \mathrm{kg}{ }^{-1}$. Alternatively, it is possible that $P$. tricornutum differs from the other species in our study in its ability to rely on $\mathrm{HCO}_{3}^{-}$uptake at low $\left[\mathrm{CO}_{2, \mathrm{aq}}\right]$, so that growth rate becomes independent of $\mathrm{CO}_{2}$ supply at any $\mathrm{CO}_{2}$ concentration. The presence of a facultative uptake system for $\mathrm{HCO}_{3}^{-}$in $P$. tricornutum in the absence of extracellular CA has been demonstrated in previous studies (Rotatore et al., 1995; Colman and Rotatore, 1995).

\subsection{Taxonomic Differences in Fractionation}

Although the correlation of $\varepsilon_{\mathrm{p}}$ with $\left[\mathrm{CO}_{2, \mathrm{aq}}\right]$ and $\mu_{\mathrm{i}}$ shows the same general trends in $S$. trochoidea as in the diatoms, fractionation by the dinoflagellate appears to differ in some aspects from that of the other species. Fractionation is lower than in $T$. punctigera, with $\varepsilon_{\mathrm{p}}$ values close to 0 in some treatments, although higher values would be expected due to smaller cell size and lower growth rates. Fractionation by the dinoflagellate is more sensitive to changes in experimental $\left[\mathrm{CO}_{2, \mathrm{aq}}\right]$ than fractionation by any of the diatom species in our study.

Taxonomic differences between diatoms and dinoflagellates with respect to both cell morphology and physiology may account for the observed differences in $\varepsilon_{\mathrm{p}}$ responses. Whereas chloroplasts and other cell organelles of diatoms are usually located in a relatively thin peripheral layer of cytoplasm between the cell wall and one or two large central vacuoles (Round et al., 1990), dinoflagellates lack such vacuoles and cell organelles are distributed over the entire cell (Van den Hoek, 1995). Another difference between the taxa is the presence of a membrane surrounding the cellulose cell wall of thecate dinoflagellates. Diatoms, in contrast, lack such a membrane around their silicate cell wall (Van den Hoek, 1995). Both the presence of an outer membrane and the distribution of chloroplasts throughout the cell may provide additional diffusive resistance for $\mathrm{CO}_{2}$ to reach the site of carboxylation, which could contribute to the greater sensitivity of $\varepsilon_{\mathrm{p}}$ to variation in $\left[\mathrm{CO}_{2, \mathrm{aq}}\right]$ in $S$. trochoidea.

Compared to diatoms, dinoflagellates have higher rates of dark respiration relative to growth rate (Geider and Osborne, 1989) so that our calculations of $\mu_{\mathrm{i}}$ for $S$. trochoidea may underestimate the actual rate of instantaneous growth. Higher 
$\mu_{\mathrm{i}}$ would lead to lower $\varepsilon_{\mathrm{p}}$ values than in diatoms under otherwise similar conditions, which is consistent with our observations. Furthermore, $\beta$-carboxylation in dinoflagellates may differ from diatoms in both the carboxylating enzyme [e.g., pyruvate carboxylase (PC) in $S$. trochoidea; PEP carboxykinase (PEPCK) in P. tricornutum and A. glacialis] and the ratio of $\beta$-carboxylase to RUBISCO activity [e.g., 0.55 in $S$. trochoidea, but 0.03 in P. tricornutum and 0.11 in A. glacialis] (Descolas-Gros and Oriol, 1992). Whether differences in $\beta$-carboxylation activity are reflected in $\varepsilon_{\mathrm{p}}$, however, depends on the ultimate fate of $\mathrm{CO}_{2}$ involved in these reactions (no effect on $\varepsilon_{\mathrm{p}}$ if $\mathrm{CO}_{2}$ is released again shortly after fixation; Raven, 1997) and on fractionation by the carboxylating enzyme. Although fractionation by PEPCK shows considerable overlap with RUBISCO (Arnelle and O'Leary, 1992), fractionation by PC has not been directly measured yet.

Finally, recent studies report the presence of form II RUBISCO in several dinoflagellate species (Morse et al., 1995; Whitney and Yellowlees, 1995). The structural similarity to RUBISCO of photosynthetic bacteria indicates that $\varepsilon_{\mathrm{p}}$ in dinoflagellates may also be significantly lower than in diatoms such as $P$. tricornutum, which possess form I RUBISCO. Again, lower $\varepsilon_{\mathrm{p}}$ values would be expected, which is consistent with our experiments with the dinoflagellate $S$. trochoidea.

\subsection{Effect of Cell Size on the Relationship of $\varepsilon_{p}$ with $\mu_{\mathrm{i}} /\left[\mathrm{CO}_{2, \mathrm{aq}}\right]$}

If we consider the entire experimental $\mathrm{CO}_{2}$ range in our study, we find significant deviations from a linear relationship between $\varepsilon_{\mathrm{p}}$ and $\mu_{\mathrm{i}} /\left[\mathrm{CO}_{2, \text { aq }}\right]$ in all species tested, which we attribute to carbon acquisition by processes other than passive diffusion of $\mathrm{CO}_{2}$. This observation is consistent with the results of Laws et al. (1997) for P. tricornutum. In contemporary ocean surface waters, however, $\mathrm{CO}_{2}$ concentrations below 7 to 10 $\mu \mathrm{mol} \mathrm{kg}{ }^{-1}$ are rarely found. To test the applicability of a linear $\varepsilon_{\mathrm{p}}$ vs $\mu_{\mathrm{i}} /\left[\mathrm{CO}_{2, \mathrm{aq}}\right]$ relationship at $\mathrm{CO}_{2}$ concentrations typically encountered by phytoplankton under natural conditions, we selected data that were obtained from incubation at $\left[\mathrm{CO}_{2, \mathrm{aq}}\right]>$ $10 \mu \mathrm{mol} \mathrm{kg}{ }^{-1}$ (Fig. 7). In addition to results from this study, we included values for the diatoms $S$. costatum (Burkhardt et al., 1999), P. tricornutum (Laws et al., 1995, 1997), and $P$. glacialis (Popp et al., 1998). The large scatter in Fig. 7a indicates that factors other than $\mu_{\mathrm{i}}$ and $\left[\mathrm{CO}_{2, \mathrm{aq}}\right]$ need to be considered to explain the variability in $\varepsilon_{\mathrm{p}}$.

An important aspect that has not yet been accounted for in our discussion is the large variation in cell size and cellular carbon content. In our experiments, variation in cellular carbon content $\left(\gamma_{\mathrm{C}}\right.$, [pmol C cell $\left.\left.{ }^{-1}\right]\right)$ for any given species was small (Table 1). Therefore, instantaneous growth rate $\mu_{\mathrm{i}}$, which does not account for differences in cellular carbon content, was sufficient in our analysis of isotopic fractionation. On the other hand, carbon-specific growth rate $\mu_{\mathrm{c}}$, defined as the product of $\gamma_{\mathrm{C}}$ and $\mu_{\mathrm{i}}$ (Eqn. 8) is more appropriate to describe $\varepsilon_{\mathrm{p}}$ when comparing cells of different size. Several authors recognized the potential effect of cell size on isotopic fractionation (e.g., Laws et al., 1995; Rau et al., 1996) which has also been demonstrated based on experimental data (Popp et al., 1998). Because carbon flux through the plasmalemma should be roughly proportional to the cell surface area, Popp et al. (1998) suggested that differences in the surface area and in the cellular $\mathrm{C}$ content between species may account for the differences in $\varepsilon_{\mathrm{p}}$ vs $\mu_{\mathrm{i}} /\left[\mathrm{CO}_{2, \text { aq }}\right]$ regressions. To test this, we plotted fractionation data from Figure $7 \mathrm{a}$ as a function of $\mu_{\mathrm{c}} /\left(\mathrm{S}\left[\mathrm{CO}_{2, \mathrm{aq}}\right]\right.$ ) (Fig. $7 b)$. Whereas cellular carbon content was directly estimated from mass spectrometric POC measurements and cell counts, cell surface area $\left(\mathrm{S},\left[\mu \mathrm{m}^{2}\right]\right.$; Table 1$)$ was determined microscopically by taking differences in cell geometry into account.

Our results indicate that the scatter observed in Figure $7 \mathrm{a}$ is reduced by considering cellular carbon content and surface area (Fig. 7b). Similar results were obtained when we used cell volume (V) rather than carbon content in combination with surface area to correct for differences in cell size (data not shown). In contrast to the linear regression shown by Popp et al. (1998), a curvilinear relationship seems more appropriate to describe the relationship between $\varepsilon_{\mathrm{p}}$ and $\mu_{\mathrm{c}} /\left(\mathrm{S}\left[\mathrm{CO}_{2, \mathrm{aq}}\right]\right)$ or $\mu_{\mathrm{i}}$ $\mathrm{V} /\left(\mathrm{S}\left[\mathrm{CO}_{2, \mathrm{aq}}\right]\right)$, even when $\mathrm{CO}_{2}$ concentrations below $10 \mu \mathrm{mol}$ $\mathrm{kg}^{-1}$ were excluded from the analysis. The flattening slope at $\mu_{\mathrm{c}} /\left(\mathrm{S}\left[\mathrm{CO}_{2, \mathrm{aq}}\right]\right)>0.002$ (Fig. 7b) can be attributed largely to the unusually high cellular carbon content of $C$. wailesii, whereas $\mu_{\mathrm{i}}$ of this species $\left(0.24-0.93 \mathrm{~d}^{-1}\right)$ lies within the range of growth rates frequently encountered in the field.

Although both a linear and a curvilinear relationship may yield similar results at $\mu_{\mathrm{c}} /\left(\mathrm{S}\left[\mathrm{CO}_{2, \mathrm{aq}}\right]\right)<0.002$, a general applicability of either function is still questionable because of the large residual variability in $\varepsilon_{\mathrm{p}}$ for any given value on the $\mathrm{x}$-axis. For a given value of $\mu_{\mathrm{c}} /\left(\mathrm{S}\left[\mathrm{CO}_{2, \mathrm{aq}}\right]\right)=6( \pm 1) \times 10^{4}$, isotopic fractionation varies between 3.0 and $20.6 \%$. Lowest $\varepsilon_{\mathrm{p}}$ values are found in the dinoflagellate $S$. trochoidea $(3.0 \%)$ and in the antarctic diatom $P$. glacialis $(6.0 \%$ ), intermediate values for small diatoms grown under nutrient-replete conditions $(S$. costatum: 13.8-14.4\%o; P. tricornutum: 15.6\%o), and maximum values for $P$. tricornutum (20.6\%o) grown under nitrogen limitation. Factors that may be responsible for this residual variability include taxon-, species-, and strain-specific differences in the mechanism of inorganic carbon acquisition. Regulated active carbon transport, induction of $\mathrm{HCO}_{3}^{-}$uptake, presence of extracellular CA, and differences in fractionation and kinetic properties of RUBISCO may lead to significant deviations of $\varepsilon_{\mathrm{p}}$ from model predictions. The particulate case of dinoflagellates has been discussed in the previous section. A comparison of field data by Kukert and Riebesell (1998) also indicates a large scatter in the $\varepsilon_{\mathrm{p}}$ vs. $\mu_{\mathrm{i}} /\left[\mathrm{CO}_{2 \text {,aq }}\right]$ relationship. The authors suggested that, aside from variation in cell size, cellular $\mathrm{C}$ content, and taxon-specific differences, the nutritional status of the phytoplankton may determine $\varepsilon_{\mathrm{p}}$. This is consistent with the observation by Riebesell et al. (submitted), who reported that isotopic fractionation is also determined by the factor controlling growth rate.

Popp et al. (1998) demonstrated that the applicability of the relationship between $\varepsilon_{\mathrm{p}}$ and $\mu_{\mathrm{c}} /\left(\mathrm{S}\left[\mathrm{CO}_{2, \mathrm{aq}}\right]\right)$ to field data depends, at least, on a knowledge of $\mu_{\mathrm{i}}$ and cell size (from which cellular C content may be estimated), which complicates or even prevents the use of isotope data for the reconstruction of paleo- $\left[\mathrm{CO}_{2, \mathrm{aq}}\right]$ from mixed plankton samples. Our experimental results add further complexity to the dependence of isotopic fractionation on environmental and species-specific factors, indicating that no general relationship between $\varepsilon_{\mathrm{p}}$, $\left[\mathrm{CO}_{2, \mathrm{aq}}\right]$, and growth rate may exist which can be applied after correction for cellular C content and cell geometry. 

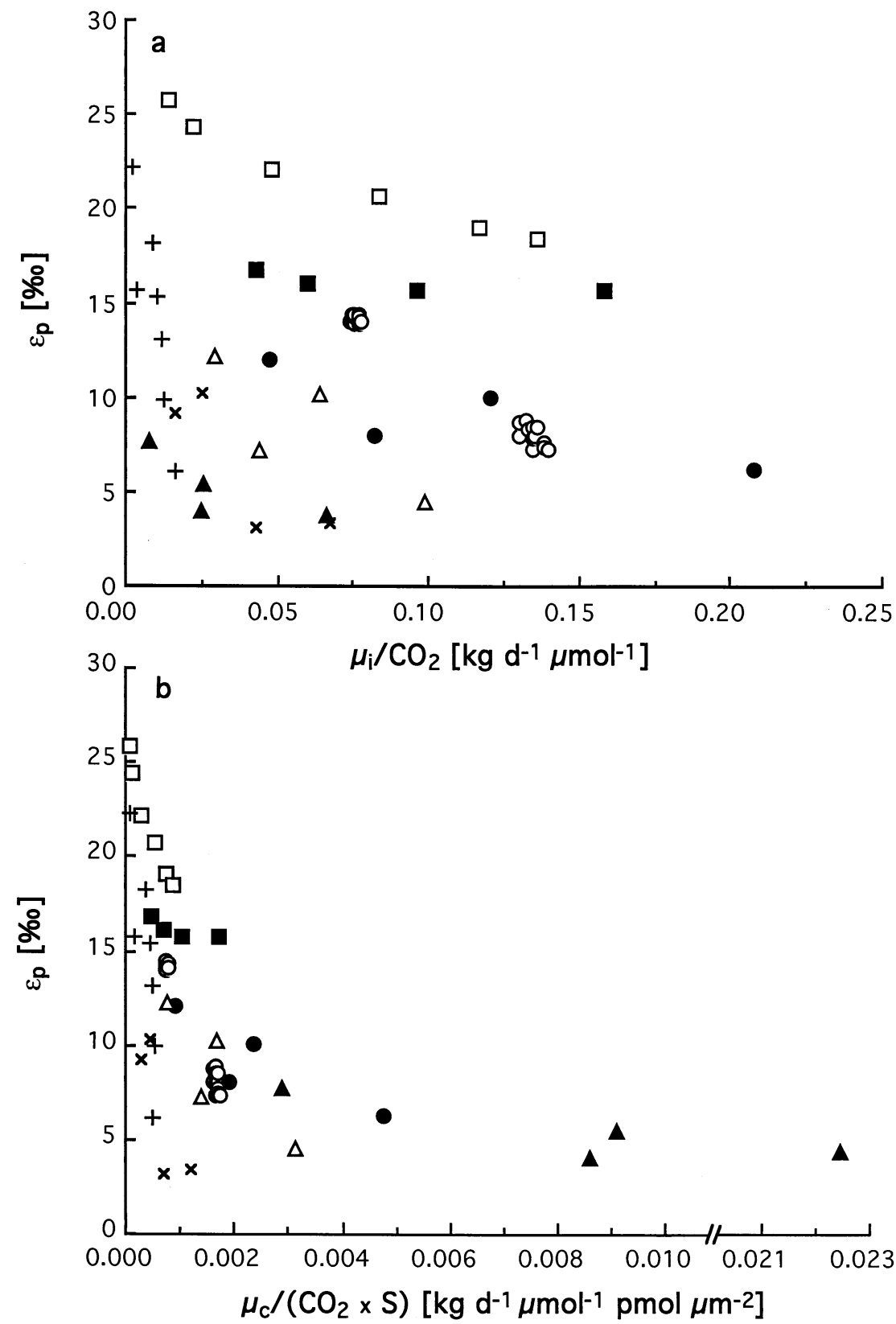

Fig. 7. Correlation of $\varepsilon_{\mathrm{p}}$ with (a) $\mu_{\mathrm{i}} /\left[\mathrm{CO}_{2, \text { aq }}\right]$ and (b) $\mu_{\mathrm{c}} /\left(\mathrm{S}^{2}\left[\mathrm{CO}_{2, \text { aq }}\right]\right)$ in marine phytoplankton grown at $\left[\mathrm{CO}_{2, \text { aq }}\right]>10$ $\mu \mathrm{mol} \mathrm{kg}{ }^{-1}$. Data for $P$. tricornutum $(\mathbf{\square})$, A. glacialis $(\mathbf{\bullet})$, T. punctigera $(\triangle)$, C. wailesii $(\boldsymbol{\Lambda})$, and $S$. trochoidea $(\times)$ are from this study. In addition, we included data for P. tricornutum ( $\square$; Laws et al., 1995), P. glacialis (+; Popp et al., 1998), and S. costatum $(\bigcirc$; Burkhardt et al., 1999).

It has often been suggested that the use of species-specific or group-specific biomarkers in isotope studies of field data (e.g., Bidigare et al., 1997) may be a valuable alternative to the analysis of mixed plankton samples. In this case, taxon-specific differences can be ignored and size effects may be negligible. Still, if an independent parameter can be found to estimate growth rates in the past, the use of $\varepsilon_{\mathrm{p}}$ vs $\mu_{\mathrm{i}} /\left[\mathrm{CO}_{2, \mathrm{aq}}\right]$ linear regressions for paleobarometry requires a careful investigation whether different kinds of growth limitation (e.g., by nutrients, light intensity, or daylength) affect the predicted relationship.

\section{CONCLUSIONS}

Our results clearly demonstrate that changes in $\mathrm{CO}_{2}$ concentration affect isotopic fractionation independent of growth rate in all species tested. Under conditions at which $\left[\mathrm{CO}_{2, \mathrm{aq}}\right]$ had no significant effect on growth rate, we observed $\mathrm{CO}_{2}$-related variation in $\varepsilon_{\mathrm{p}}$ up to $10 \%$ o depending on the species tested. With the exception of $P$. tricornutum, isotopic fractionation of all species was sensitive to changes in $\mathrm{CO}_{2}$ at concentrations $>10$ $\mu \mathrm{mol} \mathrm{kg}{ }^{-1}$, which covers the range of $\left[\mathrm{CO}_{2, \mathrm{aq}}\right]$ typically found 
in ocean surface waters. The observed correlation of $\varepsilon_{\mathrm{p}}$ with $\left[\mathrm{CO}_{2, \mathrm{aq}}\right]$ may be caused either by changes in the rate of $\mathrm{CO}_{2}$ uptake, or by the gradual induction of $\mathrm{HCO}_{3}^{-}$uptake upon a decline in $\mathrm{CO}_{2}$ supply.

We conclude from our results that processes other than the uncatalyzed passive diffusion of $\mathrm{CO}_{2}$ participate in photosynthetic carbon acquisition of all marine phytoplankton species tested. Several lines of evidence indicate that carbon transport through the plasmalemma and/or the chloroplast envelope is regulated even at the highest experimental $\left[\mathrm{CO}_{2, \mathrm{aq}}\right]$ and that $\mathrm{CO}_{2}$ uptake represents a significant fraction of gross total $\mathrm{C}$ uptake. However, no decision can be made with respect to the carbon acquisition mechanisms based on isotope data alone, which is in accordance with comments by other authors (e.g., Laws et al., 1997; Popp et al., 1998; Keller and Morel, 1999).

Growth rate, cell size, and taxon affected isotopic fractionation in our study to a similar or even greater degree than $\mathrm{CO}_{2}$ concentration. The effect of daylength and concomitant variability in the instantaneous growth rate on $\varepsilon_{\mathrm{p}}$ was speciesspecific. Limitation of growth rate by $\mathrm{CO}_{2}$ supply below a critical $\left[\mathrm{CO}_{2, \mathrm{aq}}\right]$ resulted in an increase in $\varepsilon_{\mathrm{p}}$ upon a further decline in $\left[\mathrm{CO}_{2, \mathrm{aq}}\right]$. Differences in cell size between species affected both the absolute value of $\varepsilon_{\mathrm{p}}$ (at similar $\left[\mathrm{CO}_{2, \mathrm{aq}}\right]$ and growth rate) and the magnitude of $\mathrm{CO}_{2}$-related changes in $\varepsilon_{\mathrm{p}}$. Furthermore, our data provide evidence for taxonomic differences in isotopic fractionation between the four diatoms and the dinoflagellate tested.

In contrast to Popp et al. (1998), who reported a systematic relationship between $\varepsilon_{\mathrm{p}}$ and $\mu /\left[\mathrm{CO}_{2, \mathrm{aq}}\right]$ (with different slopes but identical y-intercepts) in three eukaryotic microalgae, we observed significant deviations from this correlation in the five species of marine phytoplankton tested here, even when accounting for differences in cellular carbon content and cell geometry. Both differences in growth conditions between these studies and differences in species-specific carbon acquisition mechanisms may account for the variability in size-corrected $\varepsilon_{\mathrm{p}}$ vs. $\mu /\left[\mathrm{CO}_{2, \mathrm{aq}}\right]$ regressions. The lack of a general relationship between $\varepsilon_{\mathrm{p}}$ and $\mu /\left[\mathrm{CO}_{2, \mathrm{aq}}\right]$ prevents the use of stable carbon isotopes, measured on POC of mixed phytoplankton assemblages, for the reconstruction of $\mathrm{CO}_{2}$ even if parameters such as growth rate, cellular carbon content, and cell geometry are well constrained. This stresses the need to explore other possible relationships to adequately explain the observed $\varepsilon_{\mathrm{p}}-\mathrm{CO}_{2}$ dependence. Stable carbon isotopes in species-specific or taxonspecific compounds could provide a valuable option for the reconstruction of $\left[\mathrm{CO}_{2, \text { aq }}\right]$. Their application, however, requires careful evaluation of the potential effects of irradiance cycles, light intensity, and nutrient limitation on isotopic fractionation in "biomarker species" before a reliable calibration for the correlation of $\varepsilon_{\mathrm{p}}$ with $\left[\mathrm{CO}_{2, \mathrm{aq}}\right]$ can be established.

Acknowledgments-We thank A. Dauelsberg, C. Hartmann, C. Langreder, A. Mackensen, K.-U. Richter, and G. Traue for technical support. This research was partly supported by the project Marine Ecosystem Regulation: Trace Metal and Carbon Dioxide Limitation (MERLIM) of the European Union within the Marine Science and Technology Program under Contract MAS3-CT95-0005. This is publication 1621 of the Alfred Wegener Institute for Polar and Marine Research.

\section{REFERENCES}

Arnelle D. R. and O'Leary M. H. (1992) Binding of carbon dioxide on phosphoenol-pyruvate carboxykinase deduced from carbon kinetics isotope effects. Biochemistry 31, 4363-4368.

Badger M. R., Andrews T. J., Whitney S. M., Ludwig M., Yellowlees D. C., Leggat W., and Price G. D. (1998) The diversity and coevolution of Rubisco, plastids, pyrenoids and chloroplast-based $\mathrm{CO}_{2}$ concentrating mechanisms in algae. Can. J. Bot. 76, 1052-1071.

Bidigare R. R., Fluegge A., Freeman K. H., Hanson K. L., Hayes J. M., Hollander D., Jasper J. P., King L. L., Laws E. A., Milder J., Millero F. J., Pancost R., Popp B. N., Steinberg P. A., and Wakeham S. G. (1997) Consistent fractionation of ${ }^{13} \mathrm{C}$ in nature and in the laboratory: Growth rate effects in some haptophyte algae. Global Biogeochem. Cycles 11, 279-292.

Burkhardt S., Riebesell U., and Zondervan I. (1999) Stable carbon isotope fractionation by marine phytoplankton in response to daylength, growth rate, and $\mathrm{CO}_{2}$ availability. Mar. Ecol. Prog. Ser. 184, 31-41.

Colman B. and Rotatore C. (1995) Photosynthetic inorganic carbon uptake and accumulation in two marine diatoms. Plant Cell Environ. 18, 919-924.

Descolas-Gros C. and Oriol L. (1992) Variations in carboxylase activity in marine phytoplankton cultures. $\beta$-carboxylation in carbon flux studies. Mar. Ecol. Prog. Ser. 85, 163-169.

Francois R., Altabet M. A., and Goericke R. (1993) Changes in the $\delta^{13} \mathrm{C}$ of surface water particulate organic matter across the subtropical convergence in the SW Indian Ocean. Global Biogeochem. Cycles 7, 627-644.

Freeman K. H. and Hayes J. M. (1992) Fractionation of carbon isotopes by phytoplankton and estimates of ancient $\mathrm{CO}_{2}$ levels. Global Biogeochem. Cycles 6, 185-198.

Geider R. J. and Osborne B. A. (1989) Respiration and microalgal growth: A review of the quantitative relationship between dark respiration and growth. New Phytol. 112, 327-341.

Goericke R., Montoya J. P., and Fry B. (1994) Physiology of isotopic fractionation in algae and cyanobacteria. In Stable Isotopes in Ecology and Environmental Science (ed. K. Lajhta and R. H. Michener), pp. 187-221, Blackwell Science Publishers.

Guillard R. R. L. and Ryther J. H. (1962) Studies of marine planktonic diatoms. Can. J. Microbiol. 8, 229-239.

Guy R. D., Fogel M. L., and Berry J. A. (1993) Photosynthetic fractionation of the stable isotopes of oxygen and carbon. Plant Physiol. 101, 37-47.

Jasper J. P., Hayes J. M., Mix A. C., and Prahl F. G. (1994) Photosynthetic fractionation of ${ }^{13} \mathrm{C}$ and concentrations of dissolved $\mathrm{CO}_{2}$ in the central equatorial Pacific during the last 255,000 years. Paleoceanography 9, 781-798.

Johnston A. M. (1996) The effect of environmental variables on ${ }^{13} \mathrm{C}$ discrimination by two marine phytoplankton. Mar. Ecol. Prog. Ser. 132, 257-263.

Kaplan A. and Reinhold L. (1999) $\mathrm{CO}_{2}$ concentrating mechanisms in photosynthetic microorganisms. Ann. Rev. Plant Physiol. Plant Mol. Biol. 50, 539-570.

Keller K. and Morel F. M. M. A model of carbon isotope discrimination and active carbon uptake in phytoplankton. Mar. Ecol. Prog. Ser. 182, 295-298.

Kukert H. and Riebesell U. (1998) Phytoplankton carbon isotope fractionation during a diatom spring bloom in a Norwegian fjord. Mar. Ecol. Prog. Ser. 173, 127-137.

Laws E. A. and Bannister T. T. (1980) Nutrient- and light-limited growth of Thalassiosira fluviatilis in continuous culture, with implications for phytoplankton growth in the ocean. Limnol. Oceanogr. 25, 457-473.

Laws E. A., Popp B. N., and Bidigare R. R. (1997) Effect of growth rate and $\mathrm{CO}_{2}$ concentration on carbon isotopic fractionation by the marine diatom Phaeodactylum tricornutum. Limnol. Oceanogr. 42, 1552-1560.

Laws E. A., Popp B. N., Bidigare R. R., Kennicutt M. C., II, and Macko S. A. (1995) Dependence of phytoplankton carbon isotopic composition on growth rate and $\left[\mathrm{CO}_{2}\right]$ aq: Theoretical considerations and experimental results. Geochim. Cosmochim. Acta 59, 1131-1138.

Mehrbach C., Culberson C. H., Hawley J. E., and Pytkowicz R. M. 
(1973) Measurement of the apparent dissociation constants of carbonic acid in seawater at atmospheric pressure. Limnol. Oceanogr. 18, 897-907.

Mook W. G., Bommerson J. C., and Staverman W. H. (1974) Carbon isotope fractionation between dissolved bicarbonate and gaseous carbon dioxide. Earth Planet. Sci. Lett. 22, 169-176.

Morse D., Salois P., Markovic P., and Hastings J. W. (1995) A nuclear-encoded form II RuBisCO in dinoflagellates. Science 268, $1622-1624$.

O'Leary M. H., Madhavan S., and Paneth P. (1992) Physical and chemical basis of carbon isotope fractionation in plants. Plant Cell Environ. 15, 1099-1104.

Popp B. N., Laws E. A., Bidigare R. R., Dore J. E., Hanson K. L., and Wakeham S. G. (1998) Effect of phytoplankton cell geometry on carbon isotopic fractionation. Geochim. Cosmochim. Acta 62, 6977.

Rau G. (1994) Variations in sedimentary organic $\delta^{13} \mathrm{C}$ as a proxy for past changes in ocean and atmospheric $\mathrm{CO}_{2}$ concentrations. In Carbon Cycling in the Glacial Ocean: Constraints on the Ocean's Role in Global Change (eds. R. Zahn et al.), Vol. 17, pp. 307-321. NATO ASI Series 1.

Rau G. H., Riebesell U., and Wolf-Gladrow D. (1996) A model of photosynthetic ${ }^{13} \mathrm{C}$ fractionation by marine phytoplankton based on diffusive molecular $\mathrm{CO}_{2}$ uptake. Mar. Ecol. Prog. Ser. 133, 275285.

Rau G., Sweeney R. E., and Kaplan I. R. (1982) Plankton ${ }^{13} \mathrm{C} /{ }^{12} \mathrm{C}$ ratio changes with latitude: Differences between northern and southern oceans. Deep-Sea Res. 29, 1035-1039.

Rau G., Takahashi T., and des Marais D. J. (1989) Latitudinal variations in plankton $\delta^{13} \mathrm{C}$ : Implications for $\mathrm{CO}_{2}$ and productivity in past oceans. Nature 341, 516-518.

Rau G. H., Takahashi T., des Marais D. J., Repeta D. J., and Martin J. H. (1992) The relationship between $\delta^{13} \mathrm{C}$ of organic matter and $\left[\mathrm{CO}_{2}(\mathrm{aq})\right]$ in ocean surface water: Data from a JGOFS site in the northeast Atlantic Ocean and a model. Geochim. Cosmochim. Acta 56, 1413-1419.

Raven J. A. (1997) Inorganic carbon acquisition by marine autotrophs. Adv. Bot. Res. 27, 85-209.

Raven J. A. and Johnston A. M. (1991) Inorganic carbon acquisition mechanisms in marine phytoplankton and their implications for the use of other resources. Limnol. Oceanogr. 36, 1701-1714.

Riebesell U., Burkhardt S., Dauelsberg A., and Kroon B. Carbon isotope fractionation by a marine diatom: Dependence on the growth rate limiting resource. Mar. Ecol. Prog. Ser. (submitted).

Riebesell U. and Wolf-Gladrow D. (1995) Growth limits on phytoplankton. Nature 373, 28.

Riebesell U., Wolf-Gladrow D. A., and Smetacek V. (1993) Carbon dioxide limitation of marine phytoplankton growth rates. Nature 361, 249-251.

Roeske C. A. and O'Leary M. H. (1984) Carbon isotope effects on the enzyme-catalyzed carboxylation of ribulose bisphosphate. Biochemistry 23, 6275-6284.

Roeske C. A. and O'Leary M. H. (1985) Carbon isotope effect on carboxylation of ribulose bisphosphate catalyzed by ribulosebisphosphate carboxylase from Rhodospirillum rubrum. Biochemistry 24, 1603-1607.

Rotatore C., Colman B., and Kuzma M. (1995) The active uptake of carbon dioxide by the marine diatoms Phaeodactylum tricornutum and Cyclotella sp. Plant Cell Environ. 18, 913-918.

Round F. E., Crawford R. M., and Mann D. G. (1990) The diatoms. Biology and morphology of the genera. Cambridge University Press.

Sackett W. M., Eckelmann W. R., Bender M. L., and Bé A. W. H. (1965) Temperature dependence of carbon isotope composition in marine plankton and sediments. Science 148, 235-237.

Salon C., Mir N. A., and Canvin D. T. (1996) $\mathrm{HCO}_{3}^{-}$and $\mathrm{CO}_{2}$ leakage from Synechococcus UTEX 625. Plant Cell Environ. 19, 260-274.

Sharkey T. D. and Berry J. A. (1985) Carbon isotope fractionation of algae as influenced by an inducible $\mathrm{CO}_{2}$ concentrating mechanism. In Inorganic Carbon Uptake by Aquatic Photosynthetic Organisms (eds. W. J. Lucas and J. A. Berry), pp. 389-401, Am. Soc. Plant. Phys.

Sültemeyer D., Biehler K., and Fock H. P. (1993) Evidence for the contribution of pseudocyclic photophosphorylation to the energy requirement of the mechanism for concentrating inorganic carbon in Chlamydomonas. Planta 189, 235-242.

Van den Hoek C., Mann D. G., and Jahns H. M. (1995) Algae: An introduction to phycology. Cambridge University Press.

Whitney S. M. and Yellowlees D. (1995) Preliminary investigations into the structure and activity of ribulose bisphosphate carboxylase from two photosynthetic dinoflagellates. J. Phycol. 31, 138-146.

Wolf-Gladrow D. and Riebesell U. (1997) Diffusion and reactions in the vicinity of plankton: A refined model for inorganic carbon transport. Mar. Chem. 59, 17-34. 